\title{
Catalytic abatement of dichloromethane over transition metal oxide catalysts: Thermodynamic modelling and experimental studies
}

Zouhair El Assal $^{\mathrm{a}, \mathrm{b}}$, Satu Ojala ${ }^{\mathrm{a}^{*}}$, Mohamed Zbair ${ }^{\mathrm{a}, \mathrm{c}}$, Hafid Echchtouki ${ }^{\mathrm{d}}$, Tuomas Nevanperäa ${ }^{\mathrm{a}}$, Satu Pitkäaho $^{\mathrm{a}}$, Laurence Pirault-Roy ${ }^{\mathrm{e}}$, Mohammed Bensitel ${ }^{\mathrm{c}}$, Rachid Brahmi ${ }^{\mathrm{c}}$ and Riitta L. Keiski ${ }^{\mathrm{a}}$

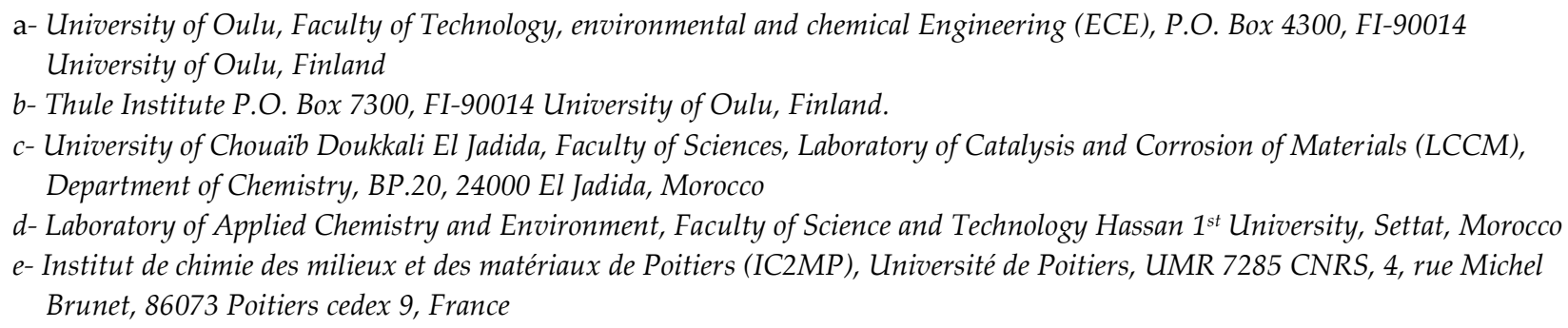

* Correspondence: satu.ojala@oulu.fi; Tel.: +358-503506098

The final publication is available at https://doi.org/10.1016/j.jclepro.2019.04.073

\begin{abstract}
Dichloromethane (DCM) is a noxious chemical that is widely used in industry. The current work focuses on the catalytic abatement of DCM from industrial effluents to minimize its harmful effects to the environment and human wellbeing. Three transition metal oxide catalysts $(\mathrm{V}, \mathrm{Cu}$ and $\mathrm{Mn})$ supported on $\gamma-\mathrm{Al}_{2} \mathrm{O}_{3}$ were synthetized for total oxidation of DCM in presence of steam. Thermodynamic modelling was used to reveal information related to the stability of the used transition metal oxides in the abatement conditions. The results showed that with $10 \mathrm{wt}-\% \mathrm{CuO}$ and 10 wt $\% \mathrm{~V}_{2} \mathrm{O}_{5}$ containing catalysts $100 \%$ conversion of DCM together with $90 \% \mathrm{HCl}$ yield and insignificant by-product formation can be achieved at temperature around $500^{\circ} \mathrm{C}$. According to modelling, $\mathrm{V}_{2} \mathrm{O}_{5}$ should be stable at the conditions of DCM oxidation, while $\mathrm{CuO}$ would be more stable at higher temperature level (decomposition of $\mathrm{CuCl}_{2}$ starts at $300^{\circ} \mathrm{C}$ ). $\mathrm{MnCl}_{2}$ remains stable until $800{ }^{\circ} \mathrm{C}$, which leads to deactivation of $\mathrm{MnO}_{2}$ catalyst. Presence of steam inhibits the poisoning
\end{abstract}


of the materials by chlorine based on thermodynamic calculation. XRF analysis supports the results of thermodynamic modelling - used $\mathrm{MnO}_{2}$ and $\mathrm{CuO}$ catalysts contain chlorine, which was not detected in case of $\mathrm{V}_{2} \mathrm{O}_{5} / \mathrm{Al}_{2} \mathrm{O}_{3} . \mathrm{CuO} / \gamma-\mathrm{Al}_{2} \mathrm{O}_{3}$ seems to be a good alternative to noble metal catalysts for the total oxidation of dichloromethane when used in the presence of steam and the temperatures above $300{ }^{\circ} \mathrm{C}$ to minimize $\mathrm{Cl}$-poisoning. The outcomes of this study showed that the prepared metal oxides are promising catalysts for to minimize pollution caused by chlorinated volatile organic compounds.

Keywords: Copper oxide, CVOC, Elimination of toxic substances, Environmental catalysis, Total oxidation, Vanadium oxide, 


\section{Introduction}

Dichloromethane (DCM) is widely used in several applications, such as a cleaning and degreasing agents, in pharmaceuticals and electronics manufacturing, film coatings, aerosol, automotive products and decaffeination of coffee (Aranzabal et al., 2014; EPA, 2011). The diverse use of DCM leads to its high emissions to the atmosphere, which cause many problems impacting human wellbeing, as described in ref. (Wexler et al., 2005), and which may even lead to consequences as serious as death (OSHA-NIOSH, 2013). The DCM carcinogenicity to humans is still under debate, since it was reported earlier that DCM might be a carcinogen (IARC, 2016). However, in 2017 the European Chlorinated Solvent Association (ECSA) stated that there is no real proof concerning the carcinogenicity of DCM to humans (ECSA, 2017). The exposure limit set by the European Union for DCM is $100 \mathrm{ppm}$ for $8 \mathrm{~h}$ and $200 \mathrm{ppm}$ in 15 min (European Commission, 2009). Due to these reasons and increasingly stringent emission legislation, demands for efficient technologies to remove and /or minimize the DCM emissions have arisen (Ojala et al., 2011).

Catalytic oxidation is probably the most interesting method for destruction of chlorinated volatile organic compounds, CVOCs, since it presents certain advantages over other possible techniques, such as lower operating temperature hindering dioxin formation and reducing energy requirement as well as lower capital costs (Aranzabal et al., 2014). Catalytic oxidation is effective in the case of diluted CVOC concentrations without using additional fuel. Furthermore, catalytic materials can be designed to be more selective towards less harmful reaction products (such as $\mathrm{HCl}$ and $\mathrm{CO}_{2}$ ) thus minimizing the production of harmful by-products. (Ojala et al., 2011)

Pt is frequently used active phase in catalytic oxidation of CVOCs. In the case of DCM, Pt catalysts supported on $\mathrm{Al}_{2} \mathrm{O}_{3}$, HFAU, $\mathrm{Ce}_{0.5} \mathrm{Zr}_{0.5} \mathrm{O}_{2}$ and $\mathrm{Al}_{2} \mathrm{O}_{3}$ modified by $\mathrm{TiO}_{2}$ and $\mathrm{CeO}_{2}$ have been investigated.. (Matějová et al., 2013; Pinard et al., 2004; Pitkäaho et al., 2013) Despite the fact that noble metal containing catalysts show high activities and selectivities in the catalytic oxidation of 
CVOCs, these types of catalysts present also some disadvantages, since they might be poisoned by chlorinated reaction products, such as $\mathrm{HCl}$ and $\mathrm{Cl}_{2}$. Another disadvantage is the higher costs of noble metals compared to metal oxides. (Aranzabal et al., 2014) Recently, the studies have been focused on the transition metal oxide catalysts, even if their activities and selectivities are typically less than those observed for the noble metals. They might, however, resist the poisoning by chlorine better than noble metals, even though it has been reported that in some cases chlorine could form volatile compounds with metal oxides (Saqer et al., 2011; Tseng et al., 2010). The most used transition metal oxide catalysts in CVOC oxidation are $\mathrm{Co}, \mathrm{Cr} F e, \mathrm{Mn}, \mathrm{Cu}, \mathrm{V}$, and $\mathrm{Cr}$. These oxides show rather high activities and selectivities. (Aranzabal et al., 2014; Yang et al., 2019; Zhang et al., 2018)

In the current work, we studied $\mathrm{CuO}, \mathrm{MnO}_{2}$ and $\mathrm{V}_{2} \mathrm{O}_{5}$ as an alternative to Pt in DCM oxidation. $\mathrm{CuO}$ supported on ceria and/or titania has shown its potential in DCM, 1,2-dichloroethane and trichloroethylene oxidation (Cao et al., 2016; Yang et al., 2019). One benefit of $\mathrm{CuO}$ is that it can be reduced at less than $200^{\circ} \mathrm{C}$, which may be beneficial for the DCM complete oxidation reaction. (Huang et al., 2011) In addition, $\mathrm{Cu}-\mathrm{Mn}$ mixed oxides supported on $\mathrm{TiO}_{2}$ have been studied in chlorobenzene oxidation (Vu et al., 2009). Suitability of Mn oxide alone in oxidation of DCM, trichloroethylene chlorobenzene and o-dichlorobenzene has been proven earlier as well (GutiérrezOrtiz et al., 2003; Tian et al., 2010; Tseng et al., 2010). Both CuO and Mn containing catalysts lead to high selectivity towards $\mathrm{CO}_{2}$ (Gutiérrez-Ortiz et al., 2003). Vanadium oxide is well-known active phase in CVOC oxidation. It has been applied in the cases of chlorobenzene, DCM, perchloroethylene, trichloroethylene and dichlorobenzene total oxidation (Gallastegi-Villa et al., 2015; Pitkäaho et al., 2012; Wu et al., 2012). It also changes the oxidation state easily similarly to copper (Weckhuysen and Keller, 2003). Compared to Copper and manganese oxides, vanadium oxide is more stable against deactivation by chlorine (Bertinchamps et al., 2008). 
In the present work, the selected metal oxides were supported on $\gamma-\mathrm{Al}_{2} \mathrm{O}_{3}$, because our earlier studies showed $\gamma-\mathrm{Al}_{2} \mathrm{O}_{3}$ to have certain advantageous properties for DCM oxidation (El Assal et al., 2017). Since we also know that especially $\mathrm{Cu}(\mathrm{I})$ oxide might deactivate in presence of $\mathrm{HCl}$, the stability of the selected oxides under the used reaction conditions was investigated by modelling.

\section{Experimental}

\subsection{Catalysts' preparation}

Aluminium oxide $\left(\mathrm{Al}_{2} \mathrm{O}_{3}\right)$ support was prepared by the sol-gel method proposed by Yoldas (Yoldas, 1975). Aluminium-tri-sec-butoxide and ultrapure water were kept under stirring at $60^{\circ} \mathrm{C}$ for $60 \mathrm{~min}$. Then, the mixture was hydrolysed by $\mathrm{HCl}$ to smooth the progress of the condensation process. Afterwards, temperature was increased to $80^{\circ} \mathrm{C}$ where the reaction was allowed to continue for 120 min. The white viscous sol was formed at the end of the stirring. The molar ratio of aluminium precursor, water and $\mathrm{HCl}$, used during the preparation was 1:100:0.1, respectively.

The prepared support was dried on a sand bath at $60{ }^{\circ} \mathrm{C}$ overnight followed by drying in a ventilated oven at $120{ }^{\circ} \mathrm{C}$ in order to eliminate the solvent from the gel. The prepared material was then heated from room temperature to $500{ }^{\circ} \mathrm{C}$ with $5{ }^{\circ} \mathrm{C} \min ^{-1}$ as the heating rate, and calcined at this temperature for $6 \mathrm{~h}$ to reach the wanted final oxide form of $\mathrm{Al}_{2} \mathrm{O}_{3}$.

The calcined support $\left(\mathrm{Al}_{2} \mathrm{O}_{3}\right)$ was wet impregnated by 30 wt-\% of metal oxides $(\mathrm{Mn}, \mathrm{V}$ and $\mathrm{Cu}$ ). Sodium permanganate monohydrate $\left(\mathrm{NaMnO}_{4} \cdot \mathrm{H}_{2} \mathrm{O}\right.$, Sigma Aldrich, 99.9\%), copper nitrate $\left(\mathrm{Cu}\left(\mathrm{NO}_{3}\right)_{2} \cdot .4 \mathrm{H}_{2} \mathrm{O}\right.$, Sigma Aldrich, $\left.99.9 \%\right)$ and vanadium acetylacetonate $\left(\mathrm{V}\left(\mathrm{C}_{10} \mathrm{H}_{14} \mathrm{O}_{5}\right)\right.$, Merck, > $98 \%$ ) were the precursors used in catalyst preparations. In addition, $10 \mathrm{wt}-\%$ of $\mathrm{V}_{2} \mathrm{O}_{5}$ and $10 \mathrm{wt}-\%$ of $\mathrm{CuO}$ catalysts supported on alumina were also prepared. The required amount of support was immersed in the solution of dissolved precursor and kept under mechanical stirring at room temperature overnight. The thermal treatment was the same as used in the support treatment. The 
catalysts are later denoted as $\mathrm{xCuAl}$ for $\mathrm{CuO} / \gamma-\mathrm{Al}_{2} \mathrm{O}_{3}, \mathrm{xVAl}$ for $\mathrm{V}_{2} \mathrm{O}_{5} / \gamma-\mathrm{Al}_{2} \mathrm{O}_{3}$ and $\mathrm{xMnAl}$ meaning $\mathrm{MnO}_{\mathrm{x}} / \gamma-\mathrm{Al}_{2} \mathrm{O}_{3}$, where $\mathrm{x}$ is the loading of the impregnated phase.

\subsection{Catalyst characterization}

The specific surface areas and pore volumes of the samples were determined by physisorption of nitrogen at $-196{ }^{\circ} \mathrm{C}$ using a Micromeritics ASAP 2020 instrument. The specific surface area was calculated using the BET method and pore size distribution was obtained by using the BJH method. Prior to adsorption experiments, the samples were degassed under vacuum at $250{ }^{\circ} \mathrm{C}$ during $2 \mathrm{~h}$.

The XRD spectra were obtained by a BRUKER-5500 diffractometer using $\mathrm{Cu}$ radiation with a wavelength of $\lambda_{\mathrm{Cu}}=0.15406 \mathrm{~nm}$ and by Rigaku SmartLab $9 \mathrm{~kW}$ using Co radiation with a wavelength of $\lambda_{\mathrm{Co}}=0.178901 \mathrm{~nm}$ and a graphite monochromator for eliminating $\mathrm{K}_{\beta}$ radiation and fluorescence. The samples were scanned in a range of $2 \theta$ from $5^{\circ}$ to $90^{\circ}$ with the rate of measurement of $0.04 \% / 2 \mathrm{~s}$. The diffraction patterns obtained were compared with the library data from JCPDS.

XRF analyses were done using a PANalytical Axios-MAX apparatus equipped with a rhodium anode as a standard. To enhance the sensitivity, the power was fixed at $3 \mathrm{~kW}(60 \mathrm{kV}, 50 \mathrm{~mA})$. The analysis was done for samples in powder form (loose-powder method).

Temperature programmed desorption of ammonia ( $\left.\mathrm{NH}_{3}-\mathrm{TPD}\right)$ was carried out with an AutoChem II 2920 device. Prior the analysis, the sample was pre-treated under He flow from room temperature to $500{ }^{\circ} \mathrm{C}$ with a heating rate of $10{ }^{\circ} \mathrm{C} \mathrm{min}{ }^{-1}$, kept at this temperature for $30 \mathrm{~min}$, and then cooled down to room temperature. The adsorption of $15 \% \mathrm{NH}_{3} / \mathrm{He}$ was done during $60 \mathrm{~min}$ at room temperature, after which the sample was flushed with $\mathrm{He}$ for $30 \mathrm{~min}$. The $\mathrm{NH}_{3}$ desorption was done from room temperature to $500{ }^{\circ} \mathrm{C}$ with heating rate of $5{ }^{\circ} \mathrm{C} \mathrm{min}^{-1}$. The flow rate of the gases during analysis was fixed to $50 \mathrm{~mL} \mathrm{~min}^{-1}$. The concentration of desorbed $\mathrm{NH}_{3}$ was analysed by a TCD detector. The total quantity of acid sites was determined by integration of the observed peaks between 40 and $500{ }^{\circ} \mathrm{C}$. 
A Timegated® 532 Raman spectrometer was used for collecting the Raman spectra of fresh and used $10 \mathrm{wt}-\% \mathrm{CuO}, \mathrm{V}_{2} \mathrm{O}_{5}$ and $\mathrm{MnO}_{2}$ catalysts and alumina support. The TG-Raman device uses a $532 \mathrm{~nm}$ pulsed laser and CMOS SPAD detector. The analysis was done in the range from 200 to $1200 \mathrm{~cm}^{-1}$ with a spectral resolution of $10 \mathrm{~cm}^{-1}$.

\subsection{Catalytic oxidation of dichloromethane}

DCM oxidation experiments were carried out in a fixed-bed tubular reactor operating under atmospheric pressure. The DCM (Sigma Aldrich and Algol, $99.0 \%$ ) concentration used was 500 ppm and the experiments were carried out in presence 1.5 vol- $\%$ of water to ensure sufficient selectivity towards $\mathrm{HCl}$. The total flow of the reaction mixture was set to be $1 \mathrm{~L} \mathrm{~min}^{-1}$ through the catalyst bed. The temperature range used in the light-off test was from 100 to $500{ }^{\circ} \mathrm{C}$ with heating rate of $5{ }^{\circ} \mathrm{C} \mathrm{min}^{-}$ 1. The tests were repeated at least once to verify the results. More details of the experimental set-up are described elsewhere (Pitkäaho et al., 2012).

Selected DCM oxidation tests were done with $100 \mathrm{mg}$ of catalyst sample giving a high gas hourly space velocity (GHSV) equivalent to $704867 \mathrm{~h}^{-1}$ during the experiments. The second set of the tests for studying the amount of active phase were done with $400 \mathrm{mg}$, which gives GHSV of 143 $793 \mathrm{~h}^{-1}$. The catalysts were sieved to obtain a $0.25-0.5 \mathrm{~mm}$ granule size in order to avoid the effect of diffusion during DCM oxidation (more details related to this issue can be found from (El Assal et al., 2017)).

\subsection{Modelling}

The formation and the stability of $\mathrm{Mn}, \mathrm{Cu}$ and $\mathrm{V}$ chlorides in the used reaction conditions were evaluated by modelling with HSC Chemistry 6 software. The equilibrium compositions versus temperature have been calculated by the Gibbs energy minimization method. The input concentrations corresponded to our real experimental mixture. The total concentration of the compounds was fixed 
to $1000 \mathrm{~mol}$ and the pressure used in the modelling was 1 bar. Solid phase as oxides was introduced in the modelling as input and the amounts corresponded 10 and $30 \mathrm{wt}-\%$. The different cases studied are summarized in Table 1. An additional modelling was done to check the situation also when the by-products are present in the reaction mixture. However, this did not change the results of the modelling related to metal chlorides and thus they are not presented in more detail.

Table 1.

\section{Results}

\subsection{Performance of 30 wt- \% catalysts in DCM oxidation}

The first comparison of the performance of the prepared catalysts in DCM oxidation was done over $30 \mathrm{CuAl}, 30 \mathrm{MnAl}$ and $30 \mathrm{VAl}$. The high loading of active phases was chosen in order to have an excess of transition metal oxide on the alumina support and to minimize the effect of chlorine-induced poisoning of the active phases. The results (Fig. 1) show that the conversion of DCM started at about $300^{\circ} \mathrm{C}$ for all the catalysts, and the maximum conversion achieved at $500{ }^{\circ} \mathrm{C}$ was about 65,55 and 15 $\%$ over $30 \mathrm{VAl}, 30 \mathrm{CuAl}$ and $30 \mathrm{MnAl}$, respectively. The light-off temperatures $\left(\mathrm{T}_{50}\right.$, temperature needed for $50 \%$ of DCM conversion) were about $480^{\circ} \mathrm{C}$ for $30 \mathrm{VAl}$ and $490{ }^{\circ} \mathrm{C}$ for $30 \mathrm{CuAl} .30 \mathrm{MnAl}$ never reached the light-off point in the used temperature range. From the final reaction products, $\mathrm{HCl}$, $\mathrm{H}_{2} \mathrm{O}$ and $\mathrm{CO}_{2}$ are those wanted. The yields of $\mathrm{HCl}$ observed for $30 \mathrm{VAl}$ and $30 \mathrm{CuAl}$ catalysts at 500 ${ }^{\circ} \mathrm{C}$ were practically the same. The Mn-containing catalyst presented an insignificant formation of $\mathrm{HCl}$ that was less than $2 \%$.

\section{Fig. 1.}




\section{Fig. 2.}

The main observed by-products were $\mathrm{CO}$ and $\mathrm{CH}_{2} \mathrm{O}$ over 30 wt- $\%$ of $\mathrm{Mn}-, \mathrm{Cu}-$ and $\mathrm{V}$-containing catalysts (Fig. 2). 30VAl produced higher amount of by-products than other catalysts: $185 \mathrm{ppm}$ and 25 ppm for $\mathrm{CO}$ and $\mathrm{CH}_{2} \mathrm{O}$, respectively. These undesired products were observed with low amounts over $30 \mathrm{MnAl}$, but it was only able to reach $15 \%$ conversion of DCM. In addition, the $30 \mathrm{CuAl}$ catalyst presented the lowest amounts of by-products formation even though the observed DCM conversion was about $55 \%$.

\subsection{Formation and stability of metal chlorides in the used experimental conditions}

Even though the transition metal oxide catalysts are active for DCM oxidation, copper and manganese oxide catalysts might be deactivated in the presence of $\mathrm{Cl}$-containing compounds as reported by $\mathrm{Gu}$ et al. (Gu et al., 2010) and Bertinchamps et al. (Bertinchamps et al., 2008). The deactivation of $\mathrm{Cu}$ and $\mathrm{Mn}$ oxides might occur, since they are also active in Deacon reaction to form $\mathrm{Cl}_{2}$ from $\mathrm{HCl} . \mathrm{Cl}_{2}$ and $\mathrm{HCl}$ may both cause formation of $\mathrm{CuCl}$ and $\mathrm{MnCl}_{2}$, which are not active in the DCM oxidation reaction. In order to check this issue, we used thermodynamic modelling. The conditions for the modelling were selected to represent the complete conversion of DCM in presence and absence of $\mathrm{H}_{2} \mathrm{O}$ and considering the production of $\mathrm{HCl}, \mathrm{H}_{2} \mathrm{O}$ and $\mathrm{CO}_{2}$. In addition, by-products such as $\mathrm{CH}_{2} \mathrm{O}$, $\mathrm{CH}_{3} \mathrm{Cl}$ as well as $\mathrm{CO}$ and $\mathrm{Cl}_{2}$ were included in a separate modelling study. The cases are summarized in Table 1 in connection with the experimental section.

Fig. 3 and 4 show the modelling results for $30 \mathrm{wt}-\% \mathrm{Cu}$-containing catalysts. Results for $10 \mathrm{wt}-$ $\%$ of $\mathrm{Cu}$ are presented in supplementary information (Figs. $1 \mathrm{~S}$ and $2 \mathrm{~S}$ ). The catalysts containing 10 and $30 \mathrm{wt}-\%$ of $\mathrm{Cu}$ present similar profiles regarding the $\mathrm{CuCl}_{2}$ decomposition and $\mathrm{CuO}$ formation in presence of water (Fig. 3(a) and (b)) that started at around $300^{\circ} \mathrm{C}$, at the same time with formation 
of $\mathrm{HCl} . \mathrm{CuCl}_{2}$ was no longer present after about $850^{\circ} \mathrm{C}$. No significant changes concerning the results were observed after addition of by-products and $\mathrm{Cl}_{2}$.

In absence of water in the input (Fig. 4), the start of $\mathrm{CuCl}_{2}$ decomposition was shifted to a slightly higher temperature $\left(350{ }^{\circ} \mathrm{C}\right)$ in the case of $30 \mathrm{wt}-\% \mathrm{CuO}$, and more than half of the initial amount of $\mathrm{CuCl}_{2}$ still existed at $800{ }^{\circ} \mathrm{C}$ with both loadings of $\mathrm{CuO}$. In the case when by-products and $\mathrm{Cl}_{2}$ were added to the input (See supplementary information Figs. $3 \mathrm{~S}, 4 \mathrm{~S}$ and $5 \mathrm{~S}$ ), a small formation of $\mathrm{Cl}_{2}$ started at around $500{ }^{\circ} \mathrm{C}$. Presence of $\mathrm{H}_{2} \mathrm{O}$ in the feed stream seems to lead to decomposition of $\mathrm{CuCl}_{2}$ at a lower temperature range thus improving the stability of $\mathrm{CuO}$ catalyst.

\section{Fig. 3.}

Fig. 4.

The modelling results related to the $30 \mathrm{wt}-\% \mathrm{MnO}_{2}$ are shown in supplementary material Figures $6 \mathrm{~S}$ and $7 \mathrm{~S}$, and for $10 \mathrm{wt}-\% \mathrm{MnO}_{2}$ catalysts in Figures $8 \mathrm{~S}$ and $9 \mathrm{~s}$. The results showed in the presence of water (Fig. $6 \mathrm{~S}(\mathrm{a})$ ), that amount of $\mathrm{MnCl}_{2}$ starts to decrease from the beginning up to $650{ }^{\circ} \mathrm{C}$ where it reaches the minimum and starts to increase again. At the same time, maxima in $\mathrm{HCl}$ and $\mathrm{MnO}_{2}$ formation are observed. Similar results were observed for $10 \mathrm{wt}-\% \mathrm{MnO}_{2}$ with only difference in amounts of the produced $\mathrm{MnCl}_{2}$ and reacted $\mathrm{MnO}_{2}$. According to the thermodynamic modelling, some amount of $\mathrm{MnCl}_{2}$ is always present in equilibrium conditions. In absence of water (Fig. 7S(a)), similar results were obtained as in the presence of water. However, the amount of $\mathrm{MnCl}_{2}$ was higher in absence of water in the studied temperature range. 
In presence of water in the input and when $\mathrm{Cl}_{2}$ was added to the output (Fig. $6 \mathrm{~S}(\mathrm{~b})$ ), we observed a different situation. $\mathrm{Cl}_{2}$ is present from the beginning (at low temperature) and starts to decrease after $100{ }^{\circ} \mathrm{C} . \mathrm{MnCl}_{2}$ formation starts at $150{ }^{\circ} \mathrm{C}$ and is still present after $850{ }^{\circ} \mathrm{C}$. The $\mathrm{HCl}$ amount starts to increase at $100{ }^{\circ} \mathrm{C}$ and reaches the maximum at around $650{ }^{\circ} \mathrm{C}$. Based on this information we assume that the poisoning of $\mathrm{MnO}_{2}$ is possible even at high temperatures when $\mathrm{Cl}_{2}$ is present. In absence of water in the input and in presence of $\mathrm{Cl}_{2}$ in the output (Fig. $7 \mathrm{~S}(\mathrm{~b})$ ), the formation of $\mathrm{MnCl}_{2}$ is even more pronounced (about a double compared with situation when water is present). Moreover, at 800 ${ }^{\circ} \mathrm{C} 85 \%$ of initial of 10 wt- $\% \mathrm{MnO}_{2}$ can react to $\mathrm{MnCl}_{2}$ according to the thermodynamics (see supplementary information). In the case of $\mathrm{MnO}_{2}$, it seems that water has an inhibiting effect against Cl-poisoning, which might be due to the reaction of $\mathrm{MnCl}_{2}$ with $\mathrm{H}_{2} \mathrm{O}$ to form $\mathrm{Mn}(\mathrm{OH}) \mathrm{Cl}$ at low temperature $\left(230^{\circ} \mathrm{C}\right)$ or $\mathrm{Mn}_{2} \mathrm{O}_{4}$ at higher temperature (near $500^{\circ} \mathrm{C}$ ). Based on these results, we expect that poisoning of $\mathrm{MnO}_{2}$ might appear in our experimental conditions of DCM oxidation.

In the case of vanadium, the modelling did not show formation of $\mathrm{VCl}_{2}$ even in the presence of $\mathrm{Cl}_{2}$. The absence of water in the input affected the formation of $\mathrm{HCl}$. The maximum $\mathrm{HCl}$ formation in presence of water was observed at $600^{\circ} \mathrm{C}$. However, a similar maximum was never reached in the absence of water up to $850{ }^{\circ} \mathrm{C}$. In presence of water, the $\mathrm{Cl}_{2}$ amount went to zero at $600^{\circ} \mathrm{C}$, whereas without water it remained in the equilibrium composition until $850{ }^{\circ} \mathrm{C}$, which was the maximum temperature used in the modelling. The results of the modelling related to vanadia are presented in supplementary material (Figs. $10 \mathrm{~S}$ and $11 \mathrm{~S}$ ). To conclude, vanadia-containing catalysts should be rather stable in our experimental conditions. Based on the modelling and preliminary testing results, we decided to continue with copper- and vanadium-containing catalysts and decrease the loading of the active phases. Copper- and vanadium- containing catalysts seem to have better stability in the used reaction conditions. In addition, these two catalysts show better performance in DCM oxidation.

\subsection{Performance of $10 \mathrm{wt}-\%$ catalysts in DCM oxidation}


Fig. 5 shows the results of the DCM oxidation for $\mathrm{Al}_{2} \mathrm{O}_{3}, 10 \mathrm{VAl}$ and $10 \mathrm{CuAl}$. The observed activities are very good. $\mathrm{Al}_{2} \mathrm{O}_{3}$ alone is able to convert DCM fully at $475{ }^{\circ} \mathrm{C}$. The addition of 10 wt- $\%$ of vanadia does not improve the catalyst performance in terms of DCM conversion. In the case of 10 wt- $\%$ of $\mathrm{CuO}$, the DCM oxidation efficiency is reduced slightly $\left(\right.$ after $350{ }^{\circ} \mathrm{C}$ ), since $100 \%$ conversion is reached at around $500{ }^{\circ} \mathrm{C}$. The slight change after $350{ }^{\circ} \mathrm{C}$ might be due to the poisoning by chlorine.

The yield of $\mathrm{HCl}$ obtained during DCM oxidation is presented in the same Fig. 5. 10VAl present the highest yield of $\mathrm{HCl}$, reaching almost $95 \%$ at $450{ }^{\circ} \mathrm{C}$. The other catalysts reach almost the same yields (90\%), but at higher temperature. At this point, 10VAl presents the highest DCM conversion, and also the highest yield of $\mathrm{HCl}$ as the wanted final product.

\section{Fig. 5.}

From the observed by-products, the highest formation was observed for $\mathrm{CH}_{2} \mathrm{O}$ and $\mathrm{CH}_{3} \mathrm{Cl}$. The formation of the by-products is shown in Fig. 6. The major result is that $10 \mathrm{CuAl}$ presents the lowest by-product formation in the whole temperature range. The second remark is that $\mathrm{Al}_{2} \mathrm{O}_{3}$ presents lower yields of $\mathrm{CO}$ and $\mathrm{CH}_{2} \mathrm{O}$ and a higher yield of $\mathrm{CH}_{3} \mathrm{Cl}$. The higher formation of $\mathrm{CH}_{3} \mathrm{Cl}$ compared to $\mathrm{CH}_{2} \mathrm{O}$ on alumina can be explained by the higher amount of Lewis acid sites (LAS) present on the surface compared with the amount of Brønsted ones (BAS). The relationship between the type of the acid sites and the by-products distribution with the same $\mathrm{Al}_{2} \mathrm{O}_{3}$ was observed in our previous work (El Assal et al., 2017). After addition of $10 \mathrm{wt}-\%$ of $\mathrm{V}_{2} \mathrm{O}_{5}$ on alumina, we observe a change in the distribution of by-products. In this case, higher formation of $\mathrm{CH}_{2} \mathrm{O}$ is observed. This should indicate modification of the acidic properties on the material surface, and presence of a higher amount of BAS on the catalyst surface. Indeed, it has been reported before (Lin and Bai, 2003), that $\mathrm{V}_{2} \mathrm{O}_{5}$ has mainly 
BAS. To conclude, $\mathrm{CuO}$ seems to be a very interesting catalytic material for DCM oxidation, since only small amounts of by-products are observed over the whole temperature range and quite similar conversions of DCM are achieved than with $\mathrm{V}_{2} \mathrm{O}_{5}$ catalyst.

\section{Fig. 6.}

\subsection{Characterization}

Since we characterized alumina used in this study in our previous work, we summarize here shortly our results reported in (El Assal et al., 2017) as background information. The XRD patterns observed for calcined $\mathrm{Al}_{2} \mathrm{O}_{3}$ were related to gamma $(\gamma-)$ phase in addition to a presence of amorphous phase in majority. That allowed alumina to gain a high surface area of $225 \mathrm{~m}^{2} \mathrm{~g}^{-1} \cdot \mathrm{N}_{2}$ physisorption isotherm was of Type IV with hysteresis Type H2, which is characteristic of the mesoporous material with bottle-shaped pores. The observed pore size distribution was homogeneous, and the pore size was centred at around $6 \mathrm{~nm}$. The thermal desorption of pyridine and lutidine over $\mathrm{Al}_{2} \mathrm{O}_{3}$ followed by FTIR analysis revealed the presence of both Lewis (LAS) and Brønsted (BAS) acid sites. The comparison between both existing acid sites showed that the prepared $\mathrm{Al}_{2} \mathrm{O}_{3}$ support has more LAS than BAS (Table 2) on the surface. As it can also be seen from the table, pyridine is more sensitive to LAS and it does not show the existence of BAS correctly. Thus, lutidine as more sensitive to BAS, was used in quantification of BAS. More discussion on this issue can be found in (El Assal et al., 2017).

Table 2. 
The XRD pattern of calcined $10 \mathrm{wt}-\% \mathrm{Cu}$ catalyst (at $500{ }^{\circ} \mathrm{C}$ ) did not show the presence of $\mathrm{CuO}$, and only $\gamma-\mathrm{Al}_{2} \mathrm{O}_{3}$ (JCPDS file 50-0741) and the amorphous phase were observed (Fig. 7; CuAl). The result indicates that the $\mathrm{CuO}$ is highly dispersed on the alumina surface, which is in agreement with the finding of Li et al. (Li et al., 2011). The EDS mapping (Fig. 8), proves the good dispersion of copper on the surface of $\gamma-\mathrm{Al}_{2} \mathrm{O}_{3}$. From the XRD diffractograms of $10 \mathrm{VAl}$ and $30 \mathrm{VAl}$ catalysts the following phases can be identified: shcherbinaite phase of $\mathrm{V}_{2} \mathrm{O}_{5}$ and $\gamma-\mathrm{Al}_{2} \mathrm{O}_{3}$ together with an amorphous phase (Fig. 7). From the XRD analysis, it is difficult to estimate accurately the crystallite size due to the presence of the amorphous phase.

\section{Fig. 7.}

The EDS mapping in Fig. 8 was done without crushing the prepared samples and the size of the granule was between $0.25-0.5 \mathrm{~mm}$, which is the same size than that used in DCM oxidation experiments. Fig. 8 demonstrates that the prepared catalysts have good dispersion of vanadium and copper on the surface of alumina. According to the EDS mapping, copper seems to be slightly more homogeneously distributed on the surface of alumina than vanadium. The average amount determined by EDS is included in Table 3. The obtained amount was quite similar to the target value.

\section{Fig. 8.}

The elemental analysis results of the catalysts are shown in Table 3 . The analysed and expected amounts are quite similar to each other. These results show the success of the impregnation of vanadium and copper on alumina. 
Table 3.

The exhibited nitrogen adsorption-desoprtion isotherms of the prepared catalysts are all Type IV with an H2-type hysteresis loop (Fig. 9). These indicate the presence of mesoporous material and relatively large pores with a narrow opening (neck of bottle) or clusters of small spheroidal particles according to the International Union of Pure and Applied Chemistry (IUPAC) (Sing, 1982; Thommes, 2010). The obtained specific surface area of $\mathrm{CuAl}$ and VAl catalysts determined by the BET method are summarized in Table 3. The results show decreasing of the surface area after impregnation of the support, however, the pore sizes determined with the BJH method remain quite similar (Table 3). The decrease of the specific surface areas after impregnation is most probably due to the blockage of the pores in the support and quite expected after rather high loading of copper and vanadium oxides.

\section{Fig. 9.}

The thermal desorption of $\mathrm{NH}_{3}$ was used in determination of total acidity of the materials and to estimate the strength of the acid sites. Based on the analysis, all the materials show the presence of weak (w), medium (m) and strong (s) acid sites in the temperature ranges of $50-250^{\circ} \mathrm{C}, 250-400^{\circ} \mathrm{C}$ and superior than $400{ }^{\circ} \mathrm{C}$, respectively. In our case, The $\mathrm{NH}_{3}$-TPD experiment was done up to 500 ${ }^{\circ} \mathrm{C}$, because it was the maximum temperature used in DCM oxidation experiments and started to approach the $\mathrm{V}_{2} \mathrm{O}_{5}$ melting temperature $\left(690^{\circ} \mathrm{C}\right)$. The total acidities of the materials were $0.145 \mathrm{mmol}$ $\mathrm{g}^{-1}$ for $\mathrm{Al}_{2} \mathrm{O}_{3}, 0.150 \mathrm{mmol} \mathrm{g}^{-1}$ for $10 \mathrm{VAl}, 0.215 \mathrm{mmol} \mathrm{g}^{-1}$ for $30 \mathrm{VAl}$ and $0.160 \mathrm{mmol} \mathrm{g}^{-1}$ for $10 \mathrm{CuAl}$. The total acidity of the material increased after addition of active phases.

\section{Discussion}


Opposite to our expectations based on the literature (Gutiérrez-Ortiz et al., 2003; Liu et al., 2001; Wang et al., 2009, 2008), we did not find good activity for Mn-containing catalyst. This is most probably due to the formation of an unexpected form of oxide, $\mathrm{Na} 0.7 \mathrm{MnO}_{2.05}$, that seems to be less active in the studied reaction. The mixed oxide is formed due to the used $\mathrm{Mn}$ precursor and the temperature of the calcination. The same phase was observed earlier by Kappenstein et al. (Kappenstein et al., 2002) when using the same preparation procedure. Unfortunately, we did not notice the formation of the mixed oxide in the beginning, and it was observed only at the end when poor activity of Mn-containing catalyst was considered in more detail. Another reason for poor activity of the Mn-containing catalyst might be found from thermodynamic modelling. The formation of $\mathrm{MnCl}_{2}$ seems to be evident in the used reaction conditions even though we do not have information on the kinetics of the formation. Additionally, the prepared $30 \mathrm{MnAl}$ catalyst has very low specific surface area that most probably affects the activity compared with other transition metal oxides.

$10 \mathrm{CuAl}$ and 10VAl catalysts showed very good activity in DCM oxidation. In addition, by-product formation over $10 \mathrm{CuAl}$ was very small - at the level of detection of the used FTIR instrument. When we compare these results to $\mathrm{Pt} / \mathrm{Al}_{2} \mathrm{O}_{3}$ studied earlier, we observed that $\mathrm{Pt} / \mathrm{Al}_{2} \mathrm{O}_{3}$ was converting 100 $\%$ of $\mathrm{DCM}$ at around $450{ }^{\circ} \mathrm{C}$ with a high yield of $\mathrm{HCl}$. The formation of the by-products, $\mathrm{CO}, \mathrm{CH}_{2} \mathrm{O}$ and $\mathrm{CH}_{3} \mathrm{Cl}$ was higher than that for $10 \mathrm{CuAl}$ catalyst reaching maxima of 55, 35 and $20 \mathrm{ppm}$, respectively, in the temperature range between 350 and $400{ }^{\circ} \mathrm{C}$. In the current work we observed that $\mathrm{V}_{2} \mathrm{O}_{5}$ addition on $\mathrm{Al}_{2} \mathrm{O}_{3}$ modifies the type of acid sites on the material based on the distribution of the by-products. The similar modification of surface acidity was observed also in the case of $\mathrm{Pt} / \mathrm{Al}_{2} \mathrm{O}_{3}$ (El Assal et al., 2017). Analogous observations were not made with $\mathrm{CuO}$ due to the very low byproduct formation.

In our earlier research, we compared properties and performance of different support materials, and we observed that higher total acidity of a support leads to a better DCM conversion. In the current 
study, we observed that when the acidity of the material is increased after addition of copper and vanadium oxides, the DCM conversions are rather decreased than improved. This may be due to decreased specific surface area due to the blockage of the pores of $\mathrm{Al}_{2} \mathrm{O}_{3}$ after impregnation of rather high loading of used metal oxides. The relation of the total acidity of the catalysts with DCM conversion, as well as relation of the type of acid sites to by-product distribution should be studied in more detail by using in-situ techniques, for example.

To go further in the study the presence of chlorine on the catalysts, a TG Raman measurement was done for $10 \mathrm{CuAl}, 30 \mathrm{MnAl}$ and $\mathrm{Al}_{2} \mathrm{O}_{3}$. The spectra of used $\mathrm{Al}_{2} \mathrm{O}_{3}$ showed the vibrations in the area of $\mathrm{Al}-\mathrm{Cl}$ stretching vibration that did not exist for fresh $\mathrm{Al}_{2} \mathrm{O}_{3}$ indicating the presence of the chlorine on the material. For the used $10 \mathrm{CuAl}$, in addition to $\mathrm{Al}-\mathrm{Cl}$ stretching vibrations, also bands related to $\mathrm{Cu}(\mathrm{II})-\mathrm{Cl}$ stretching vibration were observed. In the case of spent manganese containing catalyst, no bands in addition to $\mathrm{Al}-\mathrm{Cl}$ stretching vibration were observed. In the case of $30 \mathrm{MnAl}$ catalyst, the signal-to-noise ratio for the measurement was rather low, complicating the interpretation of the spectra. The observations related to the presence of chlorine species on the used materials support the results of the modelling. However, based on the modelling, we expected to see more chlorine compounds on 30MnAl catalyst. This is why, we did additional XRF analysis, and as a result we observed that used $30 \mathrm{MnAl}$ catalyst contained significantly more chlorine than the used $10 \mathrm{CuAl}$ catalyst. Furthermore, the used $10 \mathrm{VAl}$ or $30 \mathrm{VAl}$ practically did not contain chlorine. These results, as well as Raman results related to $10 \mathrm{VAl}$ and $10 \mathrm{CuAl}$, are well in line with the results of thermodynamic modelling.

Spivey et al. (Spivey and Butt, 1992) have concluded in their review, that chlorine may form volatile compounds with transition metal oxides. Thus, during the XRF analysis of the used catalysts, the amounts of metal oxides were also checked. It was found that the transition metal oxide amounts in $10 \mathrm{CuAl}$ and $30 \mathrm{CuAl}$ catalysts were kept well. In contrast, the amount of $\mathrm{MnO}_{2}$ in $30 \mathrm{MnAl}$ was 
reduced by $25 \%$ and vanadium in $10 \mathrm{VAl}$ catalyst to about a half. Based on these results, we can state that the loss of $\mathrm{MnO}_{2}$ and even $\mathrm{V}_{2} \mathrm{O}_{5}$ might occur in the used reaction conditions. Loss of $\mathrm{CuO}$ was not observed, which is an interesting result. However, to study this issue more, a long-duration stability test with the used catalytic materials should be conducted.

\section{Conclusion}

The objective of this work was to study the performance of transition metal oxides ( $\mathrm{Cu}, \mathrm{Mn}$ and $\mathrm{V}$ ) in total oxidation of dichloromethane. The aim was to find alternative catalysts to often used noble metals, since noble metals are expensive and they have been reported to deactivate in the presence of chlorine-containing compounds. The selected transition metals were supported on $\gamma-\mathrm{Al}_{2} \mathrm{O}_{3}$ that was found to be a good support in our earlier studies. It was found that $\mathrm{V}_{2} \mathrm{O}_{5} / \gamma-\mathrm{Al}_{2} \mathrm{O}_{3}$ and $\mathrm{CuO} / \gamma-\mathrm{Al}_{2} \mathrm{O}_{3}$ are very good alternatives for $\mathrm{Pt} / \gamma-\mathrm{Al}_{2} \mathrm{O}_{3}$. Both of these transition metal oxides give good DCM conversion and $\mathrm{HCl}$ yields. In addition, the formation of by-products over $\mathrm{CuO} / \gamma-\mathrm{Al}_{2} \mathrm{O}_{3}$ during the whole temperature range tested is almost insignificant. The results of the thermodynamic modelling showed that in the used DCM oxidation conditions, $\mathrm{MnO}_{2}$ catalyst can be expected to deactivate with time due to formation of $\mathrm{MnCl}_{2} . \mathrm{V}_{2} \mathrm{O}_{5}$ and $\mathrm{CuO}$ are more stable. However, some chlorine was observed on spent $\mathrm{CuO}$-containing catalyst based on XRF results. The reaction conditions containing water vapour are favourable for avoiding the formation of corresponding chlorides at higher temperature (after $300^{\circ} \mathrm{C}$ ), which is the starting temperature of DCM oxidation. Loss of $\mathrm{V}_{2} \mathrm{O}_{5}$ may occur during the reaction conditions based on XRF analysis. For this reason, and the fact that $\mathrm{CuO}$ produced significantly less by-products, it seems to be the best option to replace Pt among the tested materials.

\section{Acknowledgements}


The authors are grateful to Kaisu Ainassaari and Markus Riihimäki for their help in the samples characterization. The staff of the Center of Microscopy and Nanotechnology (University of Oulu, Finland) and Institute of Chemistry of Poitiers, Materials and Natural Resources (University of Poitiers, France) are acknowledged for characterizations as well.

The work was done with the financial support of the Thule Institute, Oulu University Scholarship Foundation (Yliopiston apteekin rahasto) and Tauno Tönning Foundation. 


\section{Reference}

Aranzabal, A., Pereda-Ayo, B., González-Marcos, M.P., González-Marcos, J.A., López-Fonseca, R., González-Velasco, J.R., 2014. State of the art in catalytic oxidation of chlorinated volatile organic compounds. Chem. Pap. 68, 1169-1186.

Bertinchamps, F., Poleunis, C., Grégoire, C., Eloy, P., Bertrand, P., Gaigneaux, E.M., 2008. Elucidation of deactivation or resistance mechanisms of $\mathrm{CrO}_{\mathrm{x}}, \mathrm{VO}_{\mathrm{x}}$ and $\mathrm{MnO}_{\mathrm{x}}$ supported phases in the total oxidation of chlorobenzene via ToF-SIMS and XPS analyses. Surf. Interface Anal. 40, 231-236. https://doi.org/10.1002/sia.2627

Cao, S., Shi, M., Wang, H., Yu, F., Weng, X., Liu, Y., Wu, Z., 2016. A two-stage Ce/TiO ${ }_{2-}$ $\mathrm{Cu} / \mathrm{CeO}_{2}$ catalyst with separated catalytic functions for deep catalytic combustion of $\mathrm{CH}_{2} \mathrm{Cl}_{2}$. Chem. Eng. J. 290, 147-153. https://doi.org/10.1016/j.cej.2015.12.107

ECSA, 2017. Methylene Chloride [WWW Document]. Eur. Chlorinated Solvent Assoc. URL http://www.uwosh.edu/faculty_staff/gutow/Chem_371_S12/Sam_Stef/isham website/methylene chloride/methylene chloride.html (accessed 4.20.17).

El Assal, Z., Ojala, S., Pitkäaho, S., Pirault-Roy, L., Darif, B., Comparot, J.-D., Bensitel, M., Keiski, R.L., Brahmi, R., 2017. Comparative study on the support properties in the total oxidation of dichloromethane over Pt catalysts. Chem. Eng. J. 313, 1010-1022. https://doi.org/10.1016/j.cej.2016.10.139

EPA, 2011. Toxicological review of dichloromethane [WWW Document]. Environ. Prot. Agency. https://doi.org/http://www.epa.gov/iris/toxreviews/0070tr.pdf (accessed 9.25.13)

European Commission, 2009. Recommendation from the Scientific Committee on Occupational Exposure Limits for Acrylamide. https://doi.org/ec.europa.eu/social/BlobServlet?docId=3803\&langId=en (accessed 7.1.16)

Gallastegi-Villa, M., Aranzabal, A., Boukha, Z., González-Marcos, J.A., González-Velasco, J.R., Martínez-Huerta, M.V., Bañares, M.A., 2015. Role of surface vanadium oxide coverage support on titania for the simultaneous removal of o-dichlorobenzene and $\mathrm{NO}_{\mathrm{x}}$ from waste incinerator flue gas. Catal. Today 254, 2-11. https://doi.org/10.1016/j.cattod.2015.02.029

Gu, Y., Yang, Y., Qiu, Y., Sun, K., Xu, X., 2010. Combustion of dichloromethane using coppermanganese oxides supported on zirconium modified titanium-aluminum catalysts. Catal. Commun. 12, 277-281.

Gutiérrez-Ortiz, J.I., López-Fonseca, R., Aurrekoetxea, U., González-Velasco, J.R., 2003. Lowtemperature deep oxidation of dichloromethane and trichloroethylene by H-ZSM-5-supported manganese oxide catalysts. J. Catal. 218, 148-154.

Huang, Q., Xue, X., Zhou, R., 2011. Catalytic behavior and durability of $\mathrm{CeO}_{2}$ or/and $\mathrm{CuO}$ modified USY zeolite catalysts for decomposition of chlorinated volatile organic compounds. J. Mol. Catal. A Chem. 344, 74-82. https://doi.org/10.1016/j.molcata.2011.04.021

IARC, 2016. Dichloromethane [WWW Document]. World Heal. Organ. WHO. URL http://monographs.iarc.fr/ENG/Monographs/vol110/mono110-04.pdf (accessed 5.5.17).

Kappenstein, C., Pirault-roy, L., Guérin, M., Wahdan, T., Ali, A.A., Al-sagheer, F.A., Zaki, M.I., 2002. Monopropellant decomposition catalysts V . Thermal decomposition and reduction of permanganates as models for the preparation of supported $\mathrm{MnO}_{\mathrm{x}}$ catalysts. Appl. Catal. A, Gen. 234, 145-153. 
Li, D., Yu, Q., Li, S.S., Wan, H.Q., Liu, L.J., Qi, L., Liu, B., Gao, F., Dong, L., Chen, Y., 2011. The remarkable enhancement of CO-pretreated $\mathrm{CuO}-\mathrm{Mn}_{2} \mathrm{O}_{3} / \gamma-\mathrm{Al}_{2} \mathrm{O}_{3}$ supported catalyst for the reduction of $\mathrm{NO}$ with $\mathrm{CO}$ : The formation of surface synergetic oxygen vacancy. Chem. - A Eur. J. 17, 5668-5679. https://doi.org/10.1002/chem.201002786

Lin, C.-H., Bai, H., 2003. Surface acidity over vanadia/titania catalyst in the selective catalytic reduction for NO removal-in situ DRIFTS study. Appl. Catal. B Environ. 42, 279-287. https://doi.org/10.1016/S0926-3373(02)00240-0

Liu, Y., Wei, Z., Feng, Z., Luo, M., Ying, P., Li, C., 2001. Oxidative Destruction of Chlorobenzene and o-Dichlorobenzene on a Highly Active Catalyst: $\mathrm{MnO}_{\mathrm{x}} / \mathrm{TiO}_{2}-\mathrm{Al}_{2} \mathrm{O}_{3}$. J. Catal. 202, 200204. https://doi.org/10.1006/jcat.2001.3284

Matějová, L., Topka, P., Kaluža, L., Pitkäaho, S., Ojala, S., Gaálová, J., Keiski, R.L., 2013. Total oxidation of dichloromethane and ethanol over ceria-zirconia mixed oxide supported platinum and gold catalysts. Appl. Catal. B Environ. 142-143, 54-64.

Ojala, S., Pitkäaho, S., Laitinen, T., Niskala Koivikko, N., Brahmi, R., Gaálová, J., Matejova, L., Kucherov, A., Päivärinta, S., Hirschmann, C., Nevanperä, T., Riihimäki, M., Pirilä, M., Keiski, R.L., 2011. Catalysis in VOC Abatement. Top. Catal. 54, 1224-1256.

OSHA-NIOSH, 2013. Methylene Chloride Hazards for Bathtub Refinishers [WWW Document]. URL https://www.osha.gov/dts/hazardalerts/methylene_chloride_hazard_alert.html (accessed 12.17.15).

Pinard, L., Mijoin, J., Ayrault, P., Canaff, C., Magnoux, P., 2004. On the mechanism of the catalytic destruction of dichloromethane over Pt zeolite catalysts. Appl. Catal. B Environ. 51, $1-8$.

Pitkäaho, S., Matejova, L., Ojala, S., Gaalova, J., Keiski, R.L., 2012. Oxidation of perchloroethylene-Activity and selectivity of $\mathrm{Pt}, \mathrm{Pd}, \mathrm{Rh}$, and $\mathrm{V}_{2} \mathrm{O}_{5}$ catalysts supported on $\mathrm{Al}_{2} \mathrm{O}_{3}, \mathrm{Al}_{2} \mathrm{O}_{3}-\mathrm{TiO}_{2}$ and $\mathrm{Al}_{2} \mathrm{O}_{3}-\mathrm{CeO}_{2}$. Appl. Catal. B Environ. 113-114, 150-159.

Pitkäaho, S., Nevanperä, T., Matejova, L., Ojala, S., Keiski, R.L., 2013. Oxidation of dichloromethane over $\mathrm{Pt}, \mathrm{Pd}, \mathrm{Rh}$, and $\mathrm{V}_{2} \mathrm{O}_{5}$ catalysts supported on $\mathrm{Al}_{2} \mathrm{O}_{3}, \mathrm{Al}_{2} \mathrm{O}_{3}-\mathrm{TiO}_{2}$ and $\mathrm{Al}_{2} \mathrm{O}_{3}-\mathrm{CeO}_{2}$. Appl. Catal. B Environ. 138-139, 33-42.

Saqer, S.M., Kondarides, D.I., Verykios, X.E., 2011. Catalytic oxidation of toluene over binary mixtures of copper, manganese and cerium oxides supported on $\gamma-\mathrm{Al}_{2} \mathrm{O}_{3}$. Appl. Catal. B Environ. 103, 275-286. https://doi.org/10.1016/j.apcatb.2011.01.001

Sing, K.S.W., 1982. Reporting physisorption data for gas/solid systems with special reference to the determination of surface area and porosity. Pure Appl.Chem. 54, 2201-2218.

Spivey, J.J., Butt, J.B., 1992. Literature review: deactivation of catalysts in the oxidation of volatile organic compounds. Catal. Today 11, 465-500.

Thommes, M., 2010. Physical Adsorption Characterization of Nanoporous Materials. Chemie Ing. Tech. 82, 1059-1073. https://doi.org/10.1002/cite.201000064

Tian, W., Fan, X., Yang, H., Zhang, X., 2010. Preparation of $\mathrm{MnO}_{\mathrm{x}} / \mathrm{TiO}_{2}$ composites and their properties for catalytic oxidation of chlorobenzene. J. Hazard. Mater. 177, 887-891.

Tseng, T.K., Wang, L., Ho, C.T., Chu, H., 2010. The destruction of dichloroethane over a gammaalumina supported manganese oxide catalyst. J. Hazard. Mater. 178, 1035-1040.

Vu, V.H., Belkouch, J., Ould-Dris, A., Taouk, B., 2009. Removal of hazardous chlorinated VOCs over $\mathrm{Mn}-\mathrm{Cu}$ mixed oxide based catalyst. J. Hazard. Mater. 169, 758-765. 
Wang, X., Kang, Q., Li, D., 2009. Catalytic combustion of chlorobenzene over $\mathrm{MnO}_{\mathrm{x}}-\mathrm{CeO}_{2}$ mixed oxide catalysts. Appl. Catal. B Environ. 86, 166-175.

Wang, X., Kang, Q., Li, D., 2008. Low-temperature catalytic combustion of chlorobenzene over $\mathrm{MnO}_{\mathrm{x}}-\mathrm{CeO}_{2}$ mixed oxide catalysts. Catal. Commun. 9, 2158-2162. https://doi.org/10.1016/j.catcom.2008.04.021

Weckhuysen, B.M., Keller, D.E., 2003. Chemistry, spectroscopy and the role of supported vanadium oxides in heterogeneous catalysis. Catal. Today 78, 25-46. https://doi.org/10.1016/S0920-5861(02)00323-1

Wexler, P., Peyster, A. De, Hakkinen, P.J., Pope, C., 2005. encyclopedia of toxicology, $2^{\text {nd }}$ ed. Academic Press.

Wu, M., Ung, K.C., Dai, Q., Wang, X., 2012. Catalytic combustion of chlorinated VOCs over $\mathrm{VO}_{\mathrm{x}} / \mathrm{TiO}_{2}$ catalysts. Catal. Commun. 18, 72-75. https://doi.org/10.1016/j.catcom.2011.11.028

Yang, Y., Liu, S., Zhao, H., Li, H., Qu, R., Zhang, S., Zhu, X., Zheng, C., Gao, X., 2019. Promotional effect of doping $\mathrm{Cu}$ into cerium-titanium binary oxides catalyst for deep oxidation of gaseous dichloromethane. Chemosphere 214, 553-562. https://doi.org/10.1016/j.chemosphere.2018.09.128

Yoldas, B.E., 1975. Alumina gels that form porous transparent $\mathrm{Al}_{2} \mathrm{O}_{3}$. J. Mater. Sci. 10, 1856-1860.

Zhang, Z., Xia, H., Dai, Q., Wang, X., 2018. Dichloromethane oxidation over $\mathrm{Fe}_{\mathrm{x}} \mathrm{Zr}_{1-\mathrm{x}}$ oxide catalysts. Appl. Catal. A Gen. 557, 108-118. https://doi.org/10.1016/j.apcata.2017.12.003 


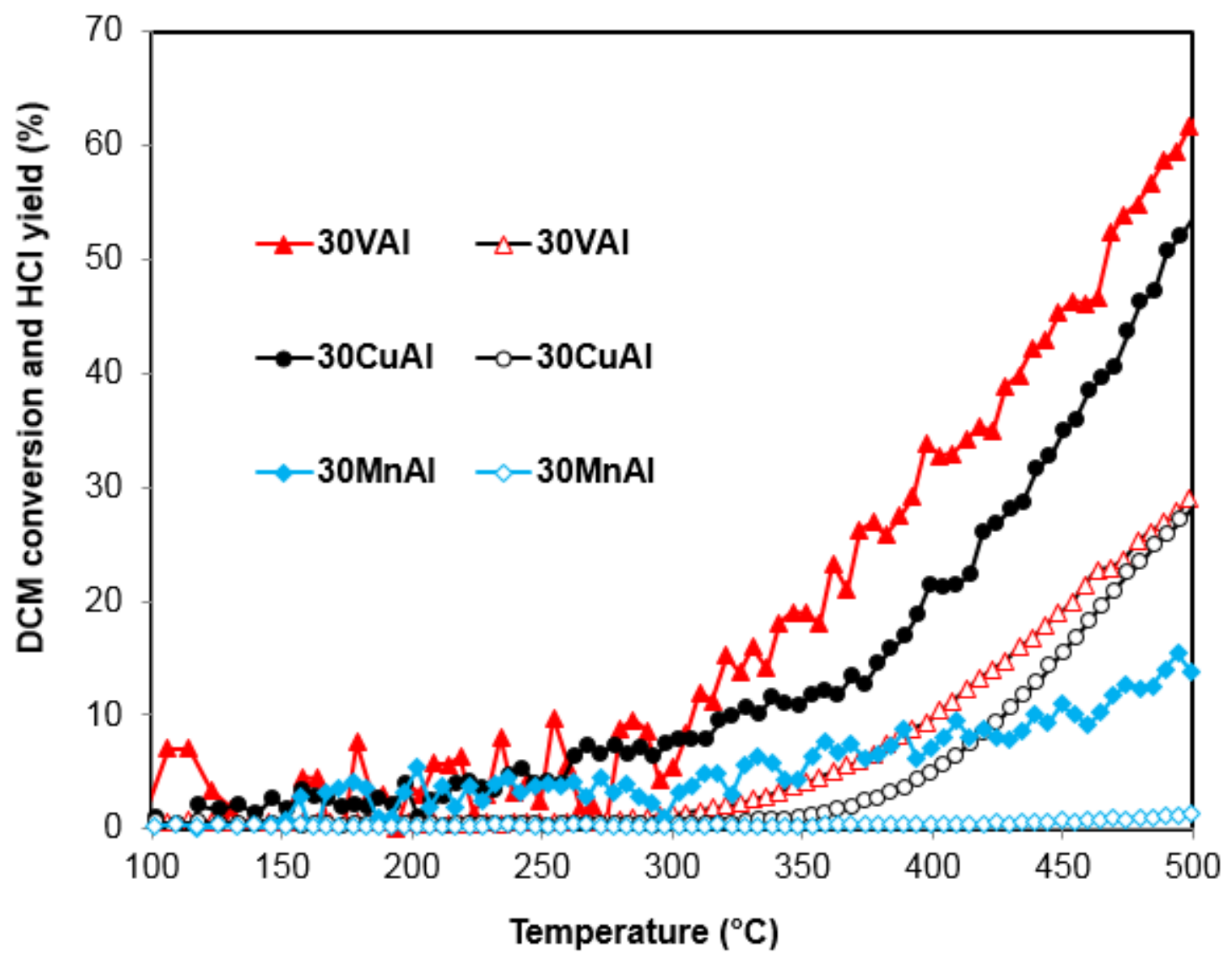

Fig. 1. Light-off curves of DCM over the different catalysts with $30 \mathrm{wt}-\%$ of loading (catalyst mass $100 \mathrm{mg}$, DCM 500 ppm, $\mathrm{H}_{2} \mathrm{O} 1.5$ vol- $\%, 1 \mathrm{~L} \mathrm{~min}^{-1}$, GHSV $704867 \mathrm{~h}^{-1}$ ). Filled symbols indicate DCM conversion and open symbols show the yield of $\mathrm{HCl}$. 

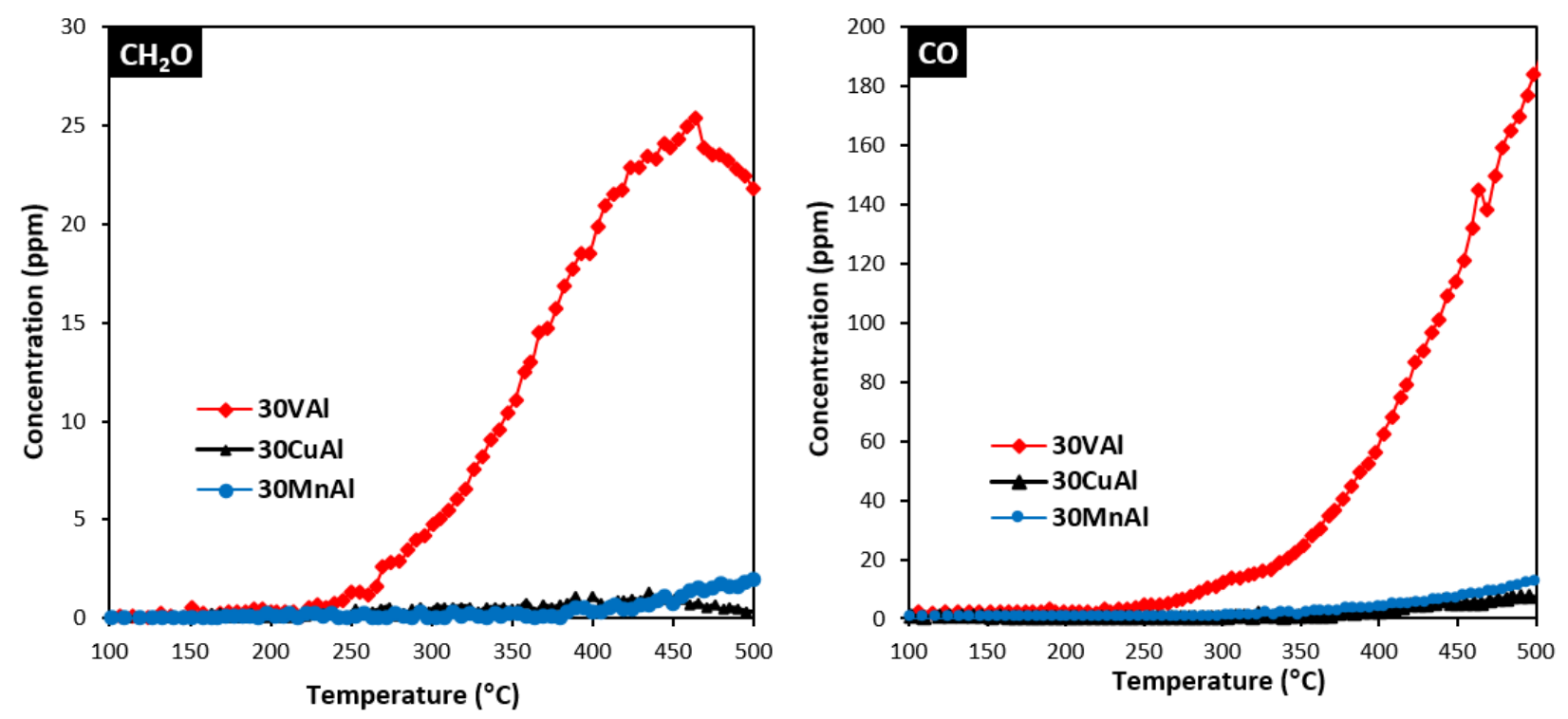

Fig. 2. Amount of major by-products over $30 \mathrm{VAl}, 30 \mathrm{CuAl}$ and $30 \mathrm{MnAl}$. The same experimental conditions were used as in Fig. 1. 

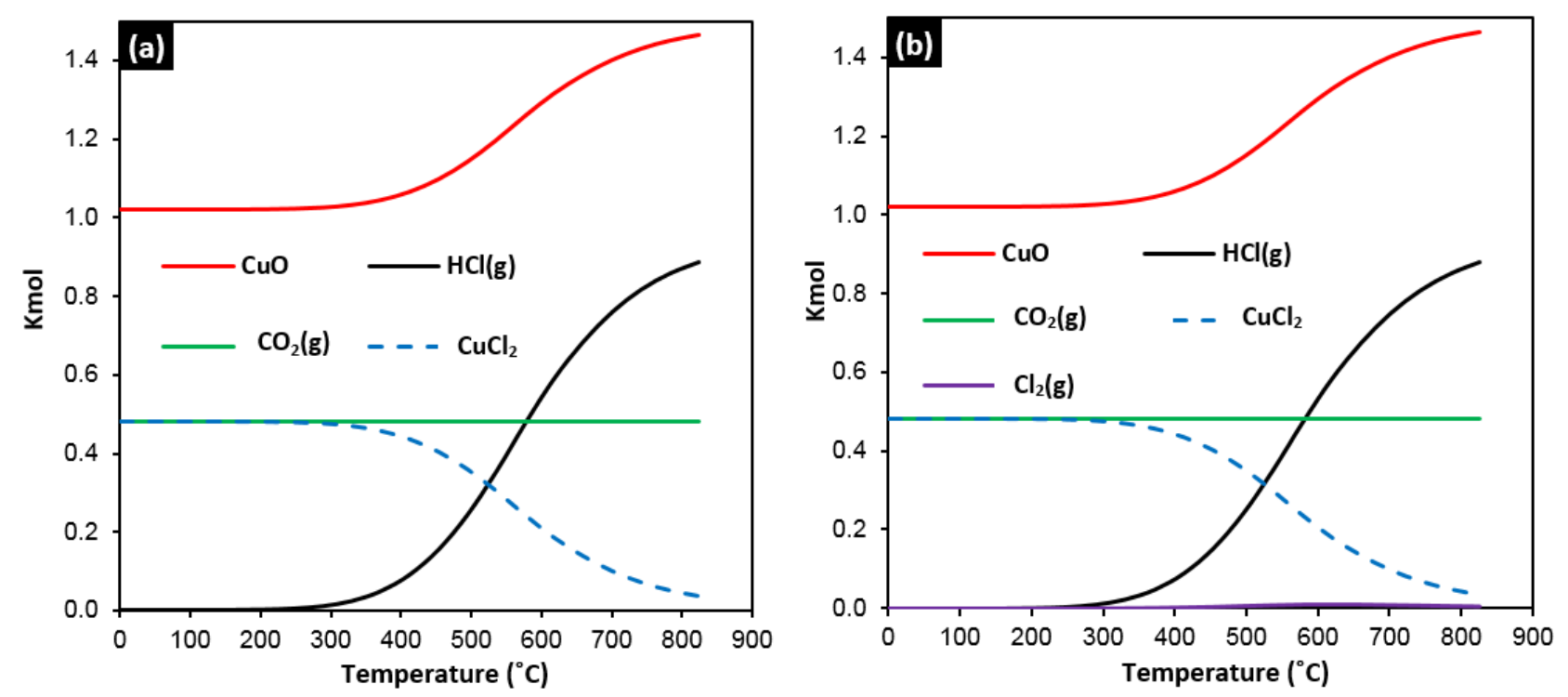

Fig. 3. Results of thermodynamic modelling for $30 \% \mathrm{CuO}$ in the presence of water in the input (Cases 1 and 2; Table 1) a) without $\mathrm{Cl}_{2}$ in the output and b) with $\mathrm{Cl}_{2}$ in the output. 

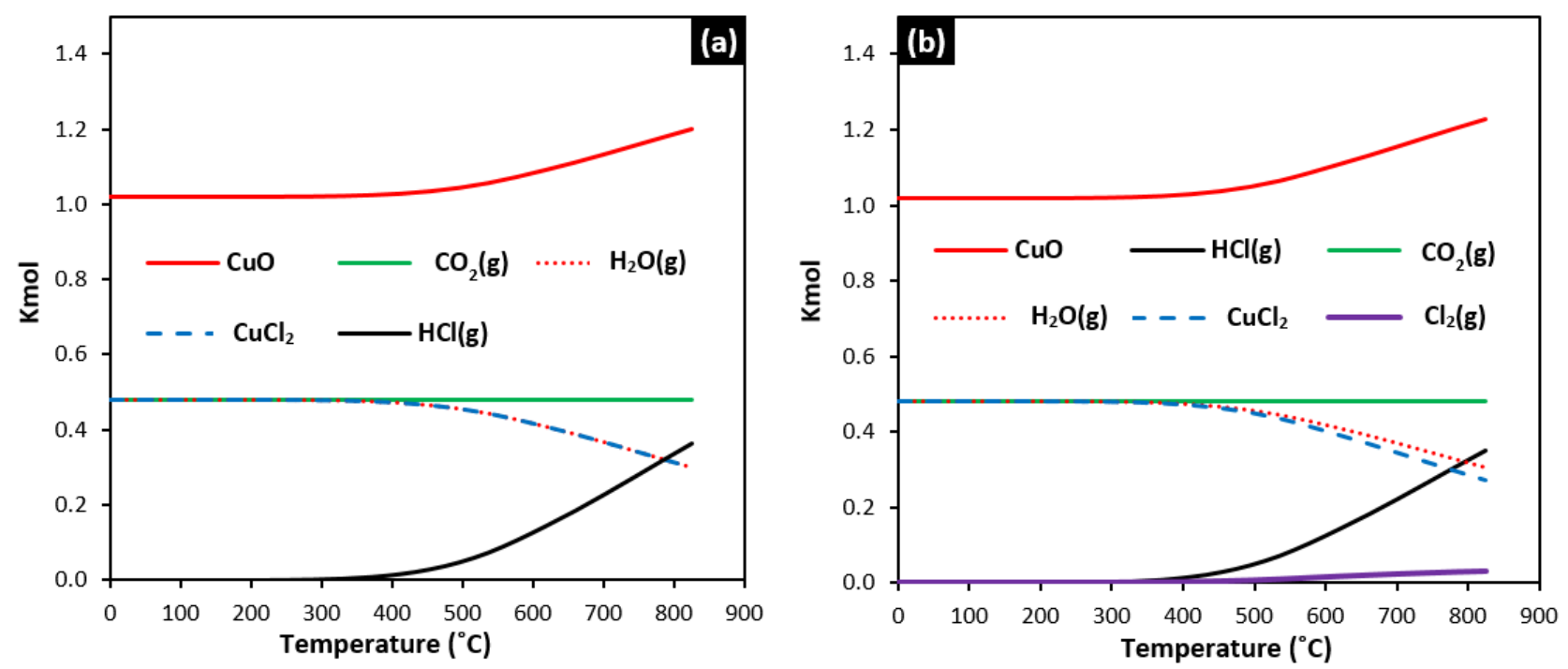

Fig. 4. Results of thermodynamic modelling for $30 \% \mathrm{CuO}$ in the absence of water in the input (Cases 4 and 5; Table 1) a) without $\mathrm{Cl}_{2}$ in the output and b) with $\mathrm{Cl}_{2}$ in the output. 


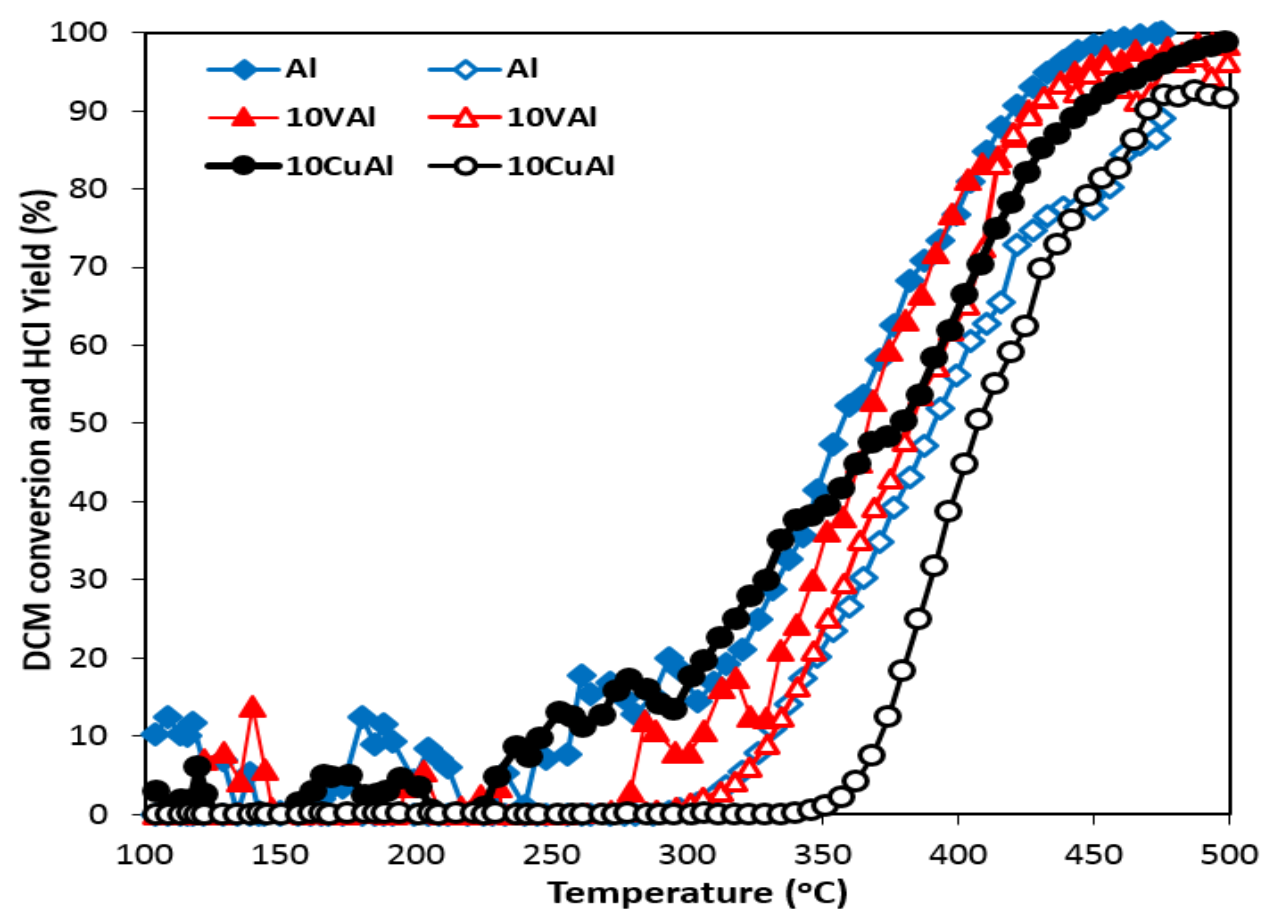

Fig. 5. Light-off curves of DCM over the different catalysts (catalyst mass $400 \mathrm{mg}$, DCM 500 ppm, $\mathrm{H}_{2} \mathrm{O} 1.5$ vol-\%, $11 \mathrm{~min}^{-1}$, GHSV $143790 \mathrm{~h}^{-1}$ ). Filled symbols are related to DCM conversion and open symbols indicate the yield of $\mathrm{HCl}$. 

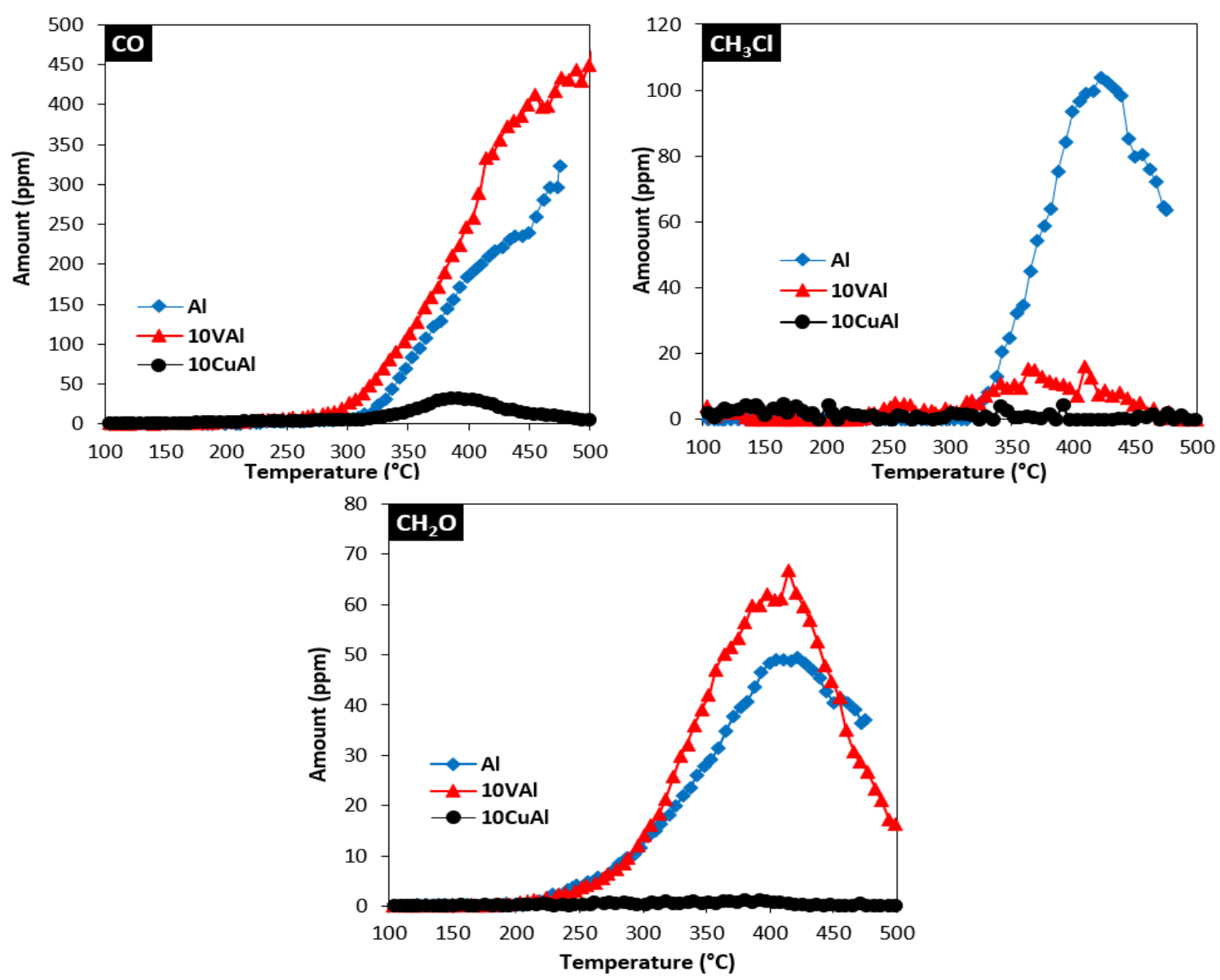

Fig. 6. Amount of major by-products over $10 \mathrm{VAl}, 10 \mathrm{CuAl}$ and $\mathrm{Al}_{2} \mathrm{O}_{3}$. The same experimental conditions were used as in Fig. 5. 

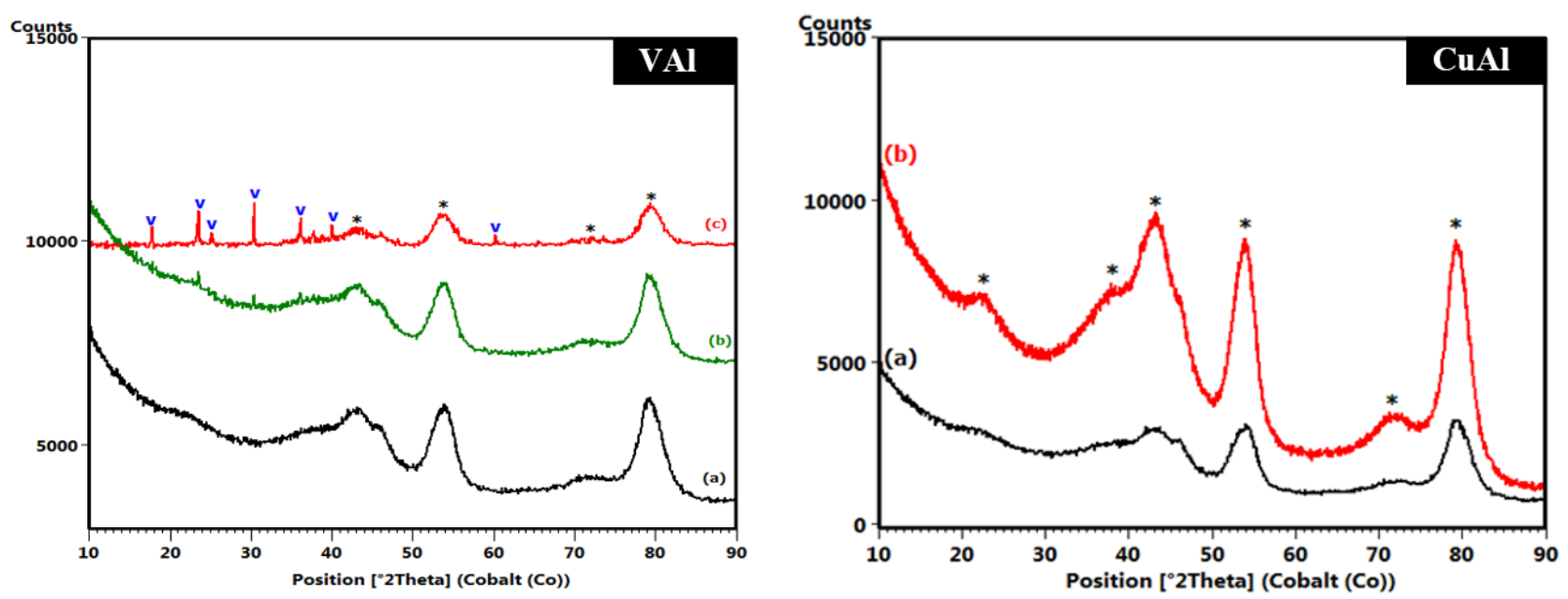

Fig. 7. XRD patterns of $\mathrm{VAl}$ catalysts: $\mathrm{Al}_{2} \mathrm{O}_{3}$ (a), $10 \mathrm{VAl}$ (b) and $30 \mathrm{VAl}$ (d) and $\mathrm{CuAl}$ catalysts: $\mathrm{Al}_{2} \mathrm{O}_{3}$ (a), 10CuAl (b). 


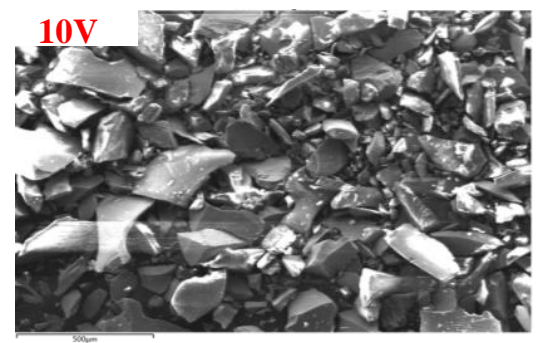

Al $K \alpha 1$

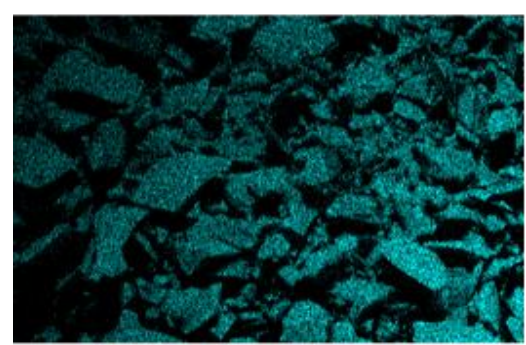

$500 \mu \mathrm{m}$

V K $\alpha 1$

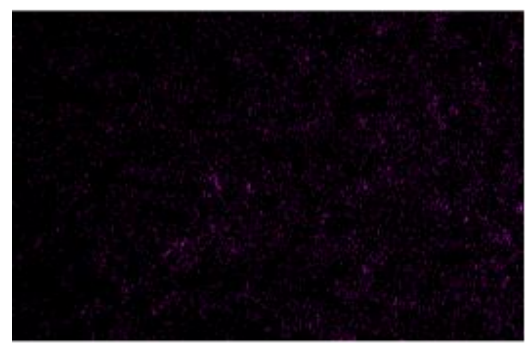

$500 \mu \mathrm{m}$

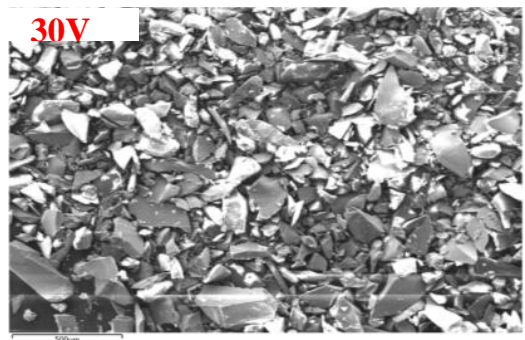

Al Ka1

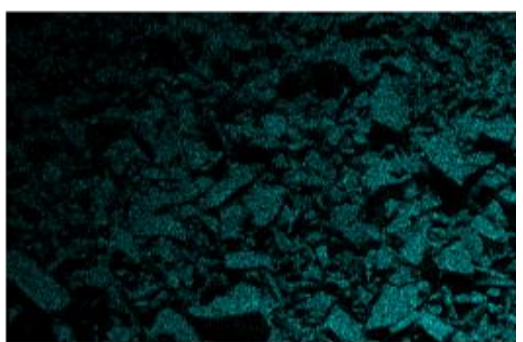

$\longdiv { 5 0 0 \mu \mathrm { m } }$

V K $\alpha 1$

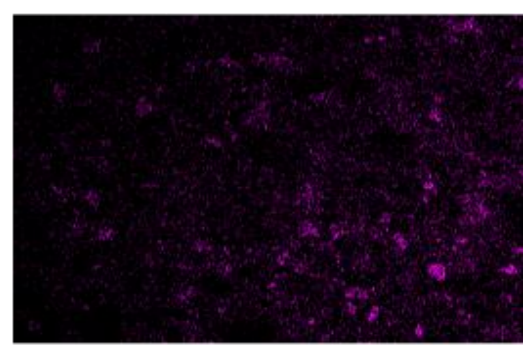

$\longdiv { 5 0 0 \mu \mathrm { m } }$

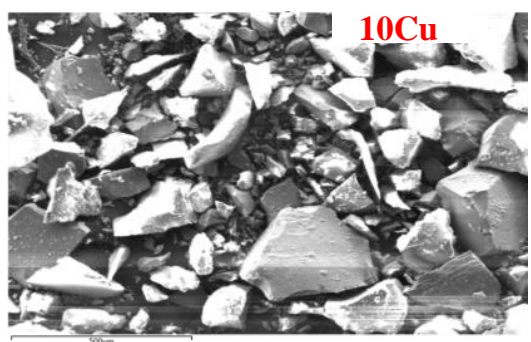

Al K $\alpha 1$

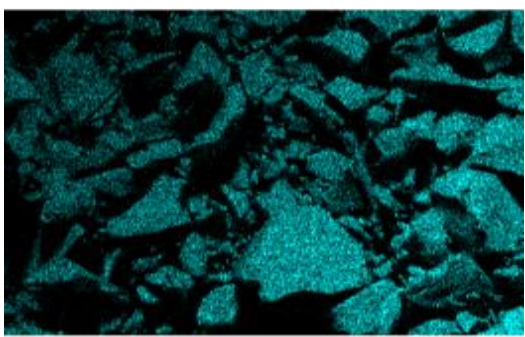

$500 \mu \mathrm{m}$

Cu L $\alpha 1,2$

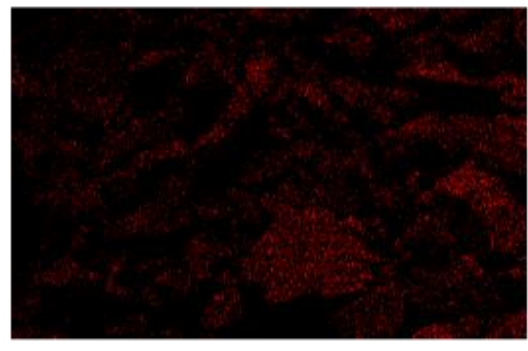

$500 \mu \mathrm{m}$

Fig. 8 EDS mapping of $\mathrm{V}$ - and $\mathrm{Cu}$ - containing catalysts. Images taken by FESEM. 


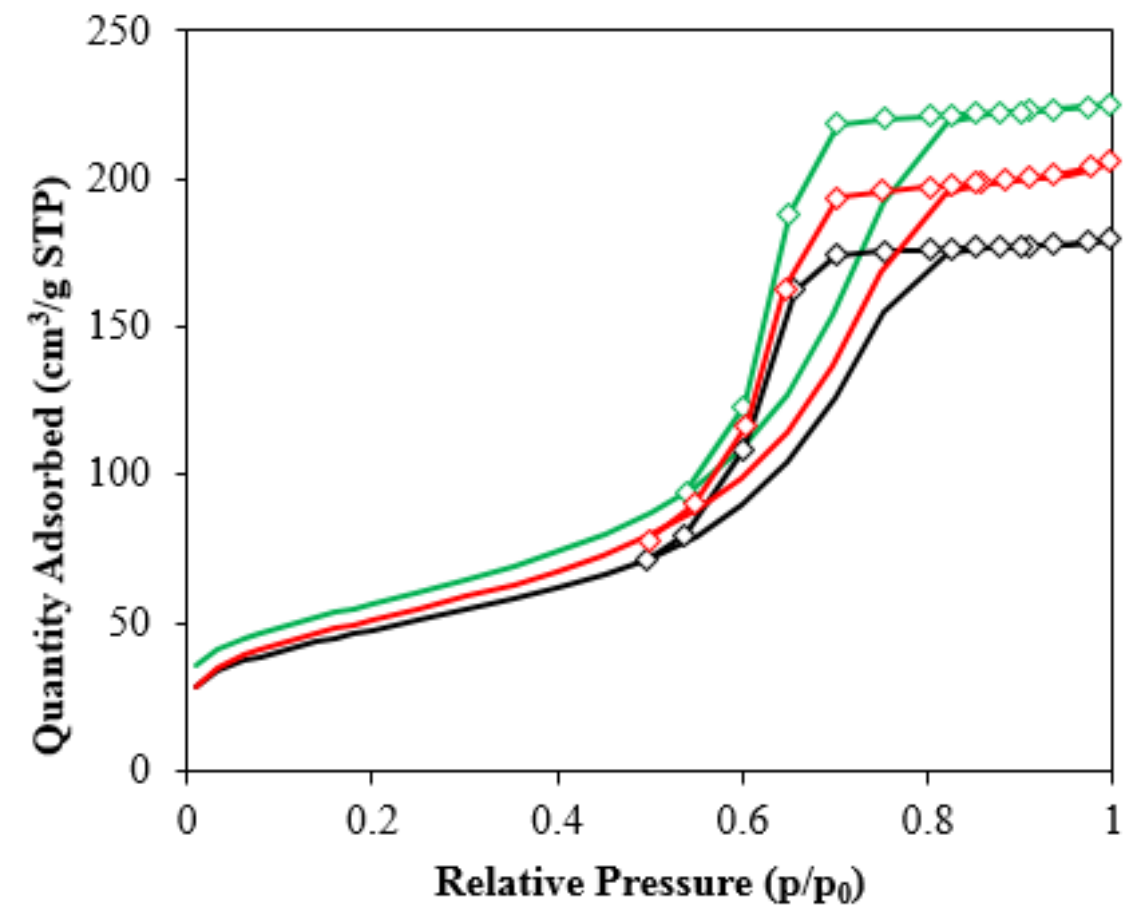

Fig. 9. Isotherm of $\mathrm{N}_{2}$-physisorption of different catalysts: green is $10 \mathrm{VAl}$, black is $30 \mathrm{VAl}$ and red is $10 \mathrm{CuAl}$, open symbols indicate desorption. 
Table 1. Studied modelling cases and used molar amounts of the compounds, (+) indicates a situation where the compound is included in calculation and (-) means not included in the output.

\begin{tabular}{ccccccccccccc}
\hline & \multicolumn{1}{c}{ Input } & \multicolumn{1}{c}{ Output } \\
\cline { 2 - 10 } & DCM & $\mathrm{H}_{2} \mathrm{O}$ & $\mathrm{O}_{2}$ & $\mathrm{~N}_{2}$ & $\mathrm{HCl}$ & $\mathrm{CO}_{2}$ & $\mathrm{CO}$ & $\mathrm{CH}_{2} \mathrm{O}$ & $\mathrm{CH}_{3} \mathrm{Cl}$ & $\mathrm{Cl}_{2}$ & $\mathrm{H}_{2} \mathrm{O}$ \\
\hline 1 & 0.48 & 15 & 200 & 784.52 & + & + & - & - & - & - & + \\
\hline 2 & 0.48 & 15 & 200 & 784.52 & + & + & - & - & - & + & + \\
\hline 3 & 0.48 & 15 & 200 & 784.52 & + & + & + & + & + & + & + \\
\hline 4 & 0.48 & 0 & 200 & 799.52 & + & + & - & - & - & - & + \\
\hline 5 & 0.48 & 0 & 200 & 799.52 & + & + & - & - & - & + & + \\
\hline 6 & 0.48 & 0 & 200 & 799.52 & + & + & + & + & + & + & + \\
\hline
\end{tabular}


Table 2. The amounts of different acid sites on $\gamma-\mathrm{Al}_{2} \mathrm{O}_{3}$ obtained by thermal desorption of pyridine and lutidine.

\begin{tabular}{|c|c|c|c|c|c|c|c|c|c|c|c|c|c|}
\hline \multirow[b]{2}{*}{ Acidity } & \multirow{2}{*}{$\begin{array}{c}\text { Probe } \\
\text { molecule }\end{array}$} & \multicolumn{2}{|c|}{$150{ }^{\circ} \mathrm{C}$} & \multicolumn{2}{|c|}{$200{ }^{\circ} \mathrm{C}$} & \multicolumn{2}{|c|}{$250^{\circ} \mathrm{C}$} & \multicolumn{2}{|c|}{$300{ }^{\circ} \mathrm{C}$} & \multicolumn{2}{|c|}{$350{ }^{\circ} \mathrm{C}$} & \multicolumn{2}{|c|}{$400{ }^{\circ} \mathrm{C}$} \\
\hline & & LAS & BAS & LAS & BAS & LAS & BAS & LAS & BAS & LAS & BAS & LAS & BAS \\
\hline \multirow{2}{*}{$\begin{array}{c}\mathrm{Al}_{2} \mathrm{O}_{3} \\
(\mu \mathrm{mol} \\
\left.\mathrm{g}^{-1}\right)\end{array}$} & Pyridine & 318 & 0 & 266 & 0 & 204 & 0 & 138 & 0 & 98 & 0 & 69 & 0 \\
\hline & Lutidine & 40 & 13 & 31 & 6 & 23 & 3 & 13 & 0 & 8 & 0 & 5 & 0 \\
\hline
\end{tabular}


Table 3. Physicochemical properties of the catalysts: $S_{\mathrm{BET}}$ is the specific surface area, Dp means pore size and am. means amorphous phase

\begin{tabular}{|c|c|c|c|c|c|c|}
\hline \multirow{2}{*}{ Catalysts } & \multirow{2}{*}{$\begin{array}{c}\mathrm{S}_{\mathrm{BET}} \\
\left(\mathrm{m}^{2} \mathrm{~g}^{-1}\right)\end{array}$} & \multirow{2}{*}{$\begin{array}{c}\mathrm{D}_{\mathrm{p}} \\
(\mathrm{nm})\end{array}$} & \multicolumn{3}{|c|}{ Metal amount* (\%) } & \multirow{2}{*}{$\begin{array}{l}\text { Identified phases } \\
\text { (XRD) }\end{array}$} \\
\hline & & & ICP & XRF & EDS & \\
\hline$* * \mathrm{Al}_{2} \mathrm{O}_{3}$ & 255 & 6 & - & - & - & $\gamma-\mathrm{Al}_{2} \mathrm{O}_{3}+\mathrm{am}$ \\
\hline 10VAl & 200 & 6.9 & - & 12 & 11 & $\begin{array}{c}\mathrm{V}_{2} \mathrm{O}_{5}+\gamma-\mathrm{Al}_{2} \mathrm{O}_{3}+ \\
\mathrm{am}\end{array}$ \\
\hline 30VAl & 169 & 6.6 & - & 27 & 30 & $\begin{array}{c}\mathrm{V}_{2} \mathrm{O}_{5}+\gamma-\mathrm{Al}_{2} \mathrm{O}_{3}+ \\
\text { am }\end{array}$ \\
\hline $10 \mathrm{CuAl}$ & 184 & 6.9 & - & 10 & 12 & $\gamma-\mathrm{Al}_{2} \mathrm{O}_{3}+\mathrm{am}$ \\
\hline$* * * \mathrm{Al}_{2} \mathrm{O}_{3}$ & 338 & 5.6 & - & - & - & $\gamma-\mathrm{Al}_{2} \mathrm{O}_{3}+\mathrm{am}$ \\
\hline 30VAl & 184 & 4.5 & 23 & - & - & $\begin{array}{c}\mathrm{V}_{2} \mathrm{O}_{5}+\gamma-\mathrm{Al}_{2} \mathrm{O}_{3}+ \\
\mathrm{am}\end{array}$ \\
\hline $30 \mathrm{CuAl}$ & 177 & 5.6 & 27 & - & - & $\mathrm{CuO}+\gamma-\mathrm{Al}_{2} \mathrm{O}_{3}+\mathrm{am}$ \\
\hline $30 \mathrm{MnAl}$ & 12 & 3.7 & 28 & - & - & $\begin{array}{c}\mathrm{Na}_{0.7} \mathrm{MnO}_{2.05}+\gamma- \\
\mathrm{Al}_{2} \mathrm{O}_{3}+\mathrm{am}\end{array}$ \\
\hline
\end{tabular}

*Calculated based on $\mathrm{MnO}_{2}, \mathrm{CuO}, \mathrm{V}_{2} \mathrm{O}_{5}$ oxides

** Adapted from our previous work [29]

*** Different set of preparation used with catalysts below 


\title{
SUPPLEMENTARY INFORMATION
}

\section{Catalytic oxidation of dichloromethane over transition metal catalysts: Thermodynamic Modelling and Experimental studies}

\author{
Zouhair El Assal ${ }^{1,2}$, Satu Ojala ${ }^{1}$, Mohamed Zbair ${ }^{1,3}$, Hafid Echchtouki ${ }^{4}$, Tuomas Nevanperä ${ }^{1}$, Satu \\ Pitkäaho1, Laurence Pirault-Roy ${ }^{5}$, Mohamed Bensitel ${ }^{3}$, Rachid Brahmi ${ }^{3}$ and Riitta L. Keiski ${ }^{1}$ \\ 1- University of Oulu, Faculty of Technology, environmental and chemical Engineering (ECE), P.O. Box 4300, FI-90014 University of \\ Oulu, Finland \\ 2- Thule Institute P.O. Box 7300, FI-90014 University of Oulu, Finland. \\ 3- University of Chouaïb Doukkali El Jadida, Faculty of Sciences, Laboratory of Catalysis and Corrosion of Materials (LCCM), \\ Department of Chemistry, BP.20, 24000 El Jadida, Morocco \\ 4- Laboratory of Applied Chemistry and Environment, Faculty of Science and Technology Hassan $1^{\text {st }}$ University, Settat, Morocco \\ 5- Institut de chimie des milieux et des matériaux de Poitiers (IC2MP), Université de Poitiers, UMR 7285 CNRS, 4, rue Michel \\ Brunet, 86073 Poitiers cedex 9, France
}

* Correspondence: satu.ojala@oulu.fi; Tel.: +358-503506098 


\section{Preparation of the catalysts}

Aluminium oxide $\left(\mathrm{Al}_{2} \mathrm{O}_{3}\right)$ support was prepared by the sol-gel method. Aluminium-tri-sec-butoxide and ultrapure water were kept under stirring at $60^{\circ} \mathrm{C}$ for $60 \mathrm{~min}$. Then, the mixture was hydrolysed by $\mathrm{HCl}$ to smooth the progress of the condensation process. Afterwards, temperature was increased to $80^{\circ} \mathrm{C}$ where the reaction was allowed to continue for $120 \mathrm{~min}$. The white viscous sol was formed at the end of the stirring. The molar ratio of aluminium precursor, water and $\mathrm{HCl}$, used during the preparation was 1:100:0.1, respectively.

The prepared support was dried on a sand bath at $60{ }^{\circ} \mathrm{C}$ overnight followed by drying in a ventilated oven at $120{ }^{\circ} \mathrm{C}$ in order to eliminate the solvent from the gel. The prepared material was then heated from room temperature to $500{ }^{\circ} \mathrm{C}$ with $5{ }^{\circ} \mathrm{C} \mathrm{min}^{-1}$ as the heating rate and calcined at this temperature for $6 \mathrm{~h}$ to reach the wanted final oxide form of $\mathrm{Al}_{2} \mathrm{O}_{3}$.

The calcined support $\left(\mathrm{Al}_{2} \mathrm{O}_{3}\right)$ was wet impregnated by 30 wt- $\%$ of metal oxides $(\mathrm{Mn}, \mathrm{V}$ and $\mathrm{Cu})$. Sodium permanganate monohydrate $\left(\mathrm{NaMnO}_{4} \cdot \mathrm{H}_{2} \mathrm{O}\right.$, Sigma Aldrich, 99.9\%), copper nitrate $\left(\mathrm{Cu}\left(\mathrm{NO}_{3}\right)_{2} \cdot 4 \mathrm{H}_{2} \mathrm{O}\right.$, Sigma Aldrich, $\left.99.9 \%\right)$ and vanadium acetylacetonate $\left(\mathrm{V}\left(\mathrm{C}_{10} \mathrm{H}_{14} \mathrm{O}_{5}\right)\right.$, Merck, > $98 \%$ ) were the precursors used in catalyst preparations. In addition, $10 \mathrm{wt}-\%$ of $\mathrm{V}_{2} \mathrm{O}_{5}$ and $10 \mathrm{wt}-\%$ of $\mathrm{CuO}$ catalysts supported on alumina were also prepared. The required amount of support was immersed in the solution of dissolved precursor and kept under mechanical stirring overnight at room temperature. The thermal treatment was the same as used in the support treatment. The catalysts are later denoted as $\mathrm{xCuAl}$ for $\mathrm{CuO} / \gamma-\mathrm{Al}_{2} \mathrm{O}_{3}, \mathrm{xVAl}$ for $\mathrm{V}_{2} \mathrm{O}_{5} / \gamma-\mathrm{Al}_{2} \mathrm{O}_{3}$ and $\mathrm{xMnAl}$ meaning $\mathrm{MnO}_{\mathrm{x}} / \gamma-\mathrm{Al}_{2} \mathrm{O}_{3}$ where $\mathrm{x}$ is the loading of the impregnated phase. 

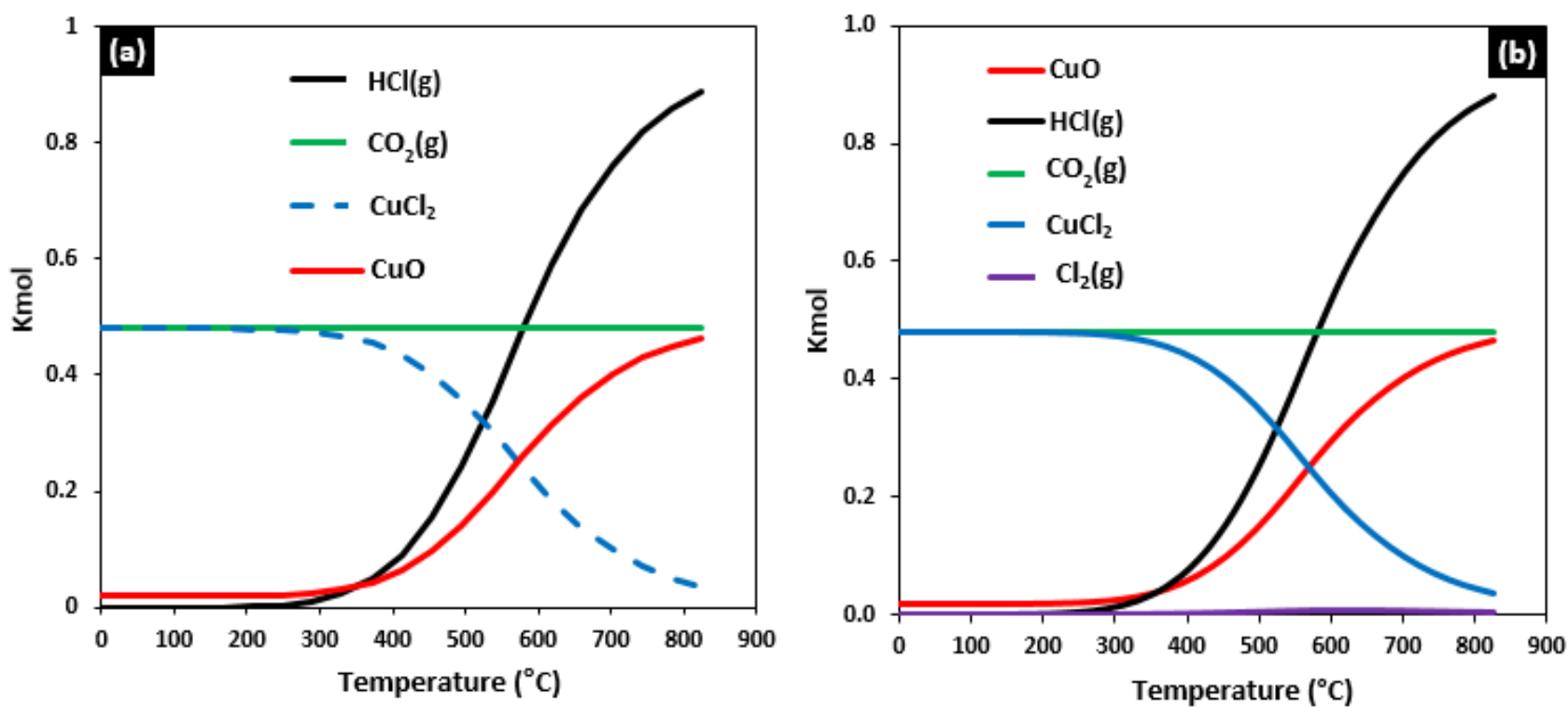

Fig. 1S. Results of thermodynamic modelling for $10 \% \mathrm{CuO}$ in the presence of water in the input (Cases 1 and 2; Table 1) a) without $\mathrm{Cl}_{2}$ in the output and b) with $\mathrm{Cl}_{2}$ in the output
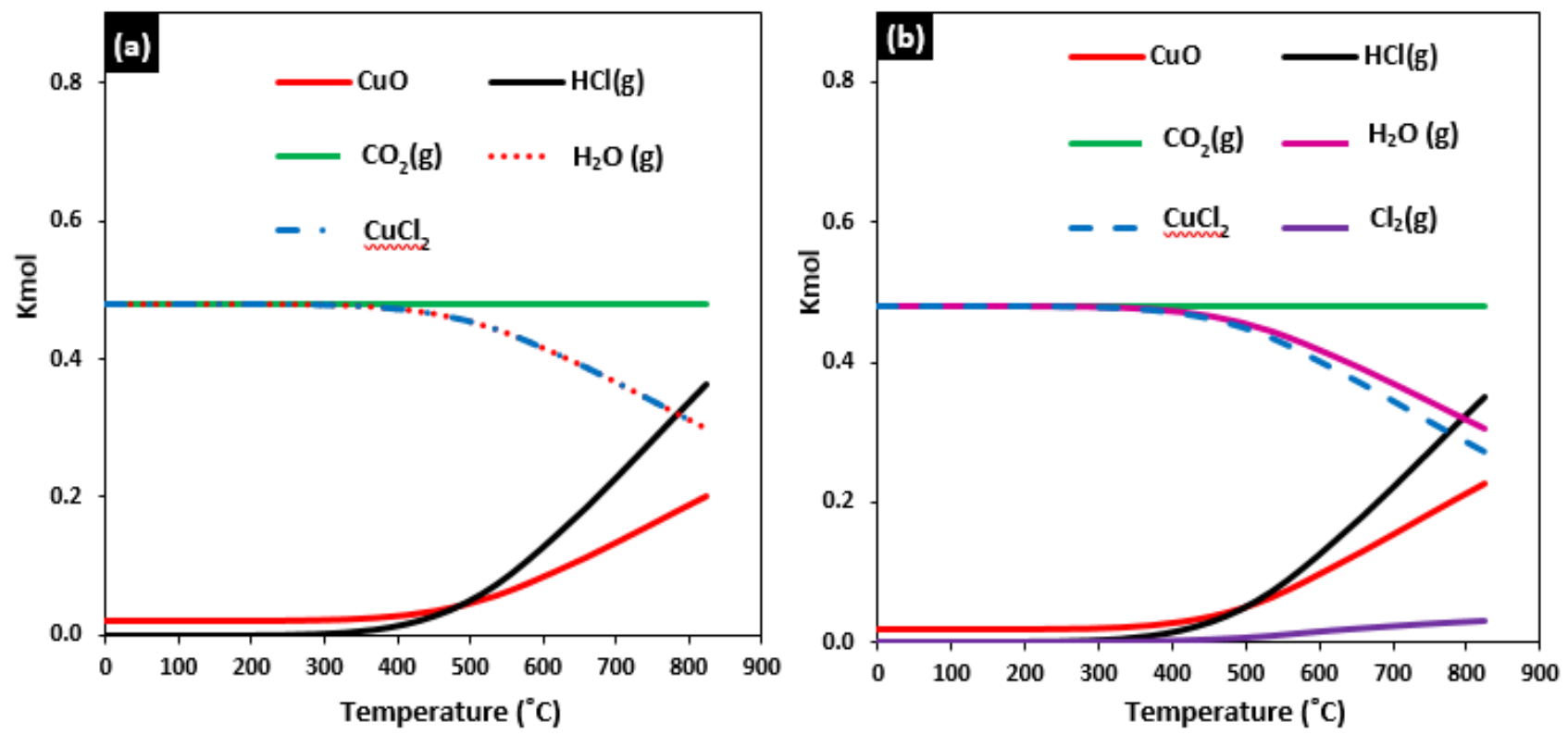

Fig. 2S. Results of thermodynamic modelling for $10 \% \mathrm{CuO}$ in the absence of water in the input (Cases 4 and 5; Table 1) a) without $\mathrm{Cl}_{2}$ in the output and b) with $\mathrm{Cl}_{2}$ in the output 

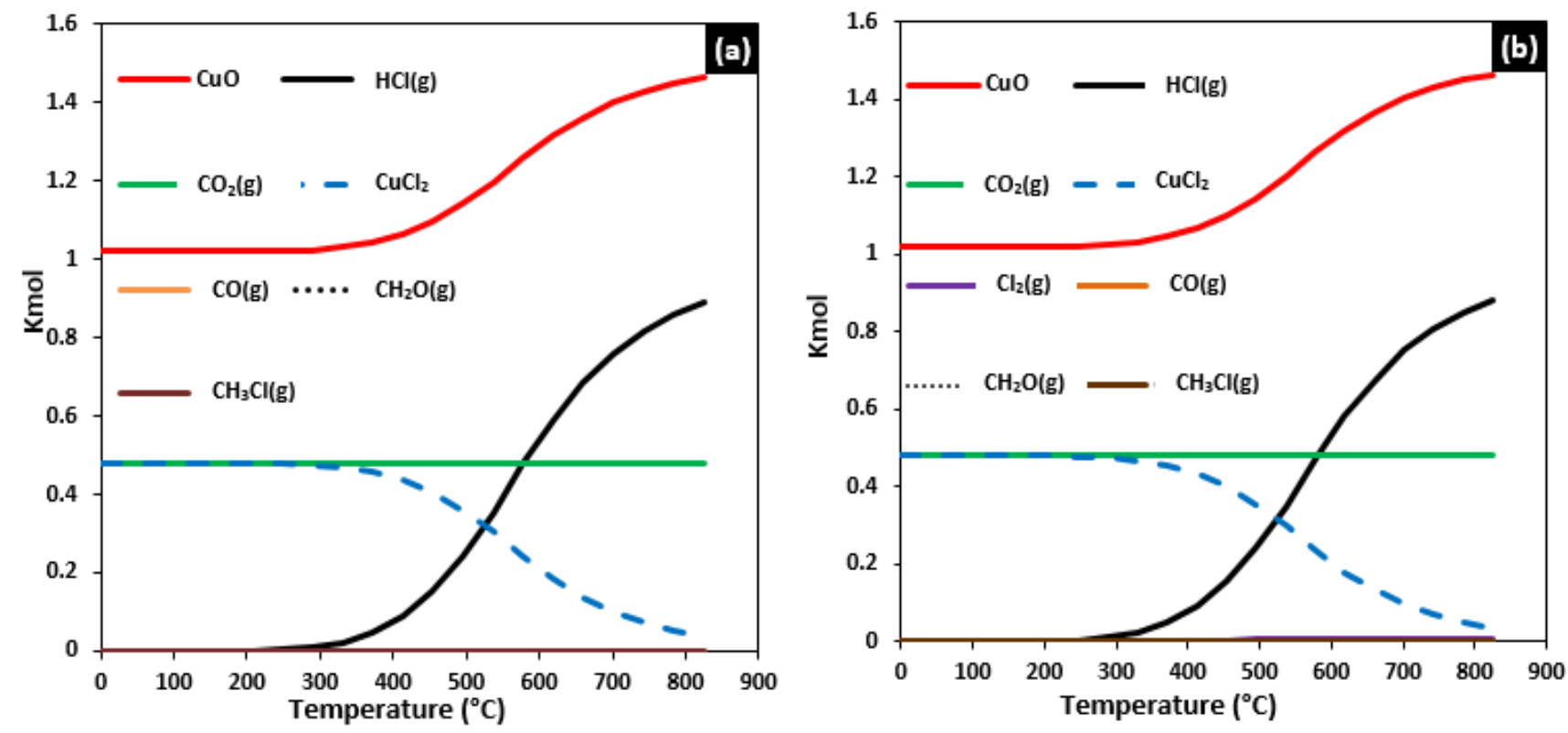

Fig. 3S. Results of thermodynamic modelling for $30 \% \mathrm{CuO}$ in the presence of water in the input and by-products in output (Cases 3; Table 1) a) without $\mathrm{Cl}_{2}$ in the output and b) with $\mathrm{Cl}_{2}$ in the output.
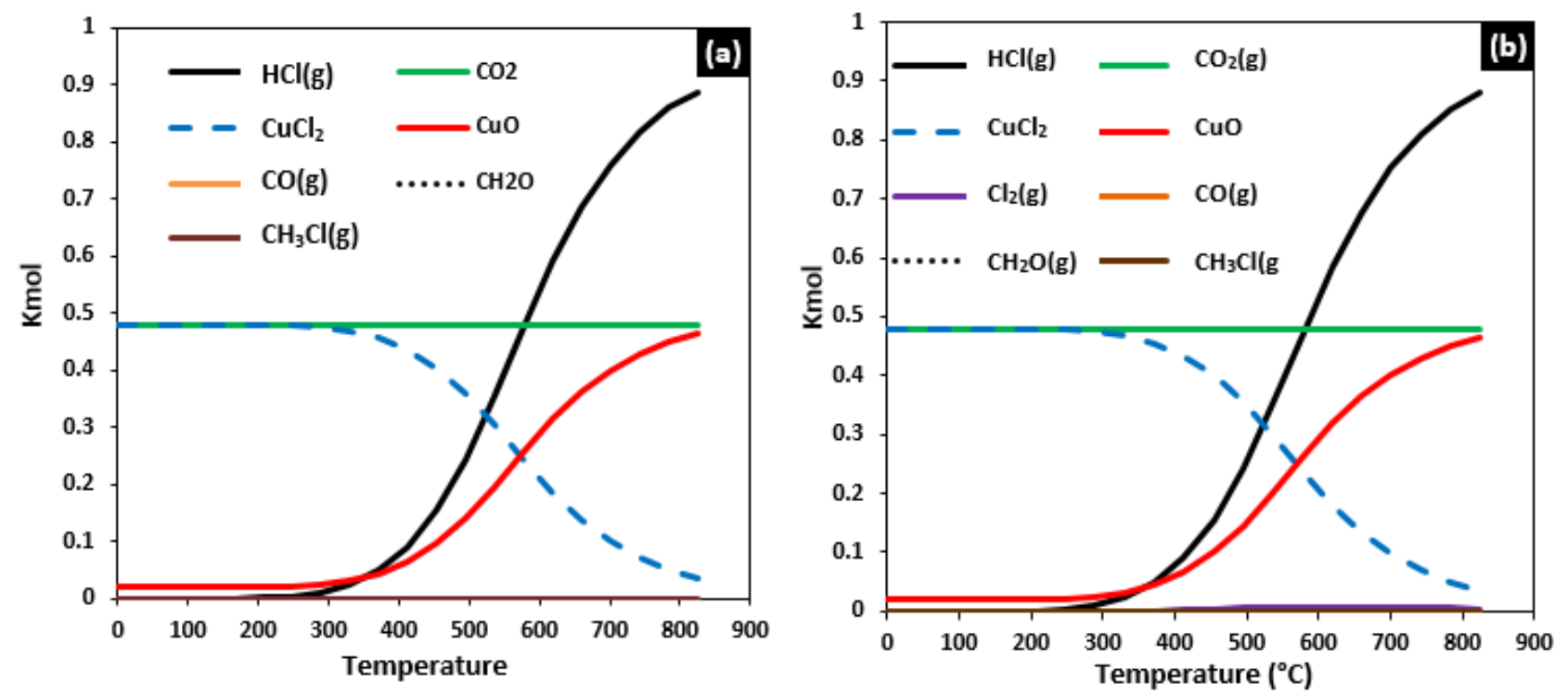

Fig. 4S. Results of thermodynamic modelling for $10 \% \mathrm{CuO}$ in the presence of water in the input and by-products in output (Cases 3; Table 1) a) without $\mathrm{Cl}_{2}$ in the output and b) with $\mathrm{Cl}_{2}$ in the output. 

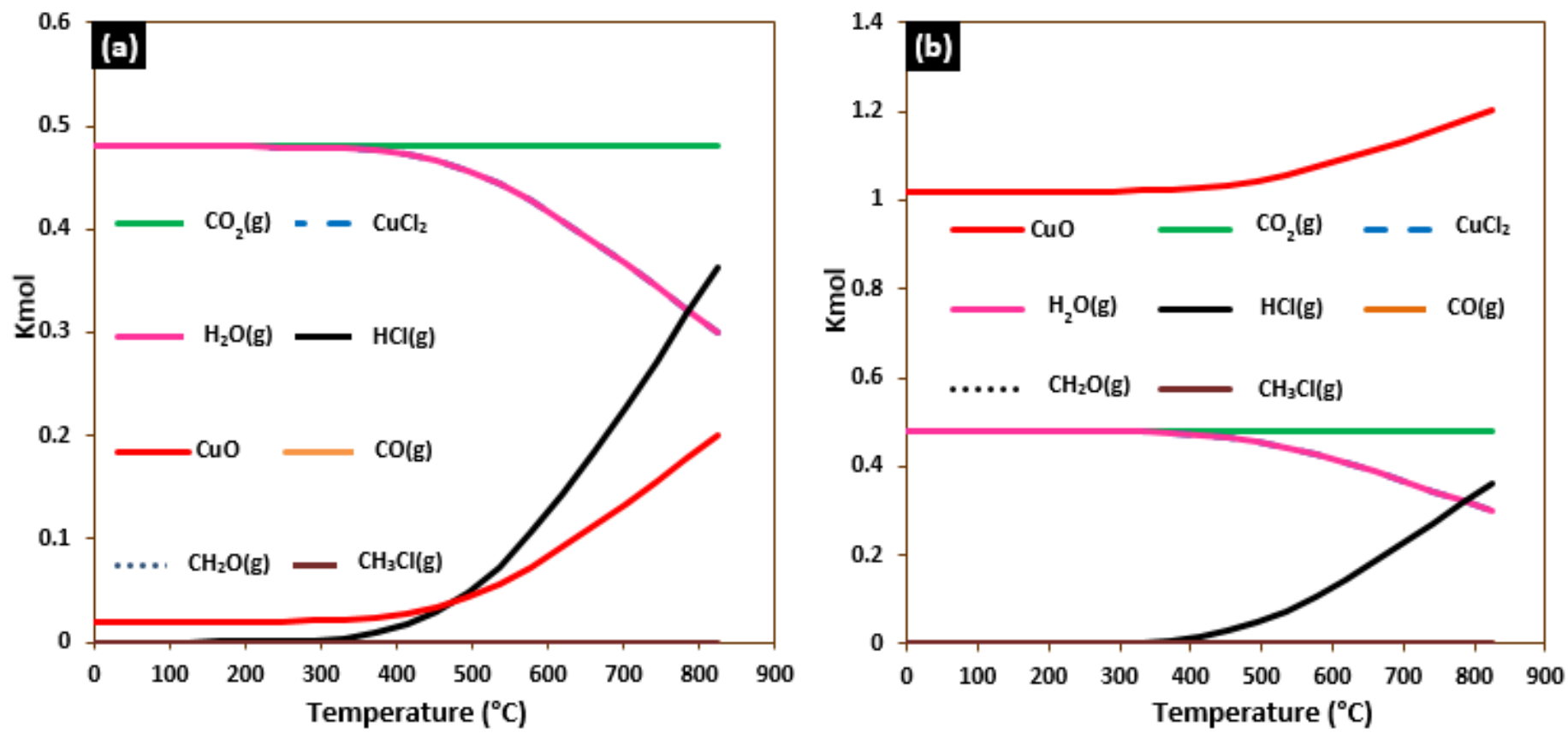

Fig. 5S. Results of thermodynamic modelling in the absence of water in the input and by-products in output (Cases 6; Table 1) a) $10 \% \mathrm{CuO}$, b) $30 \% \mathrm{CuO}$ 

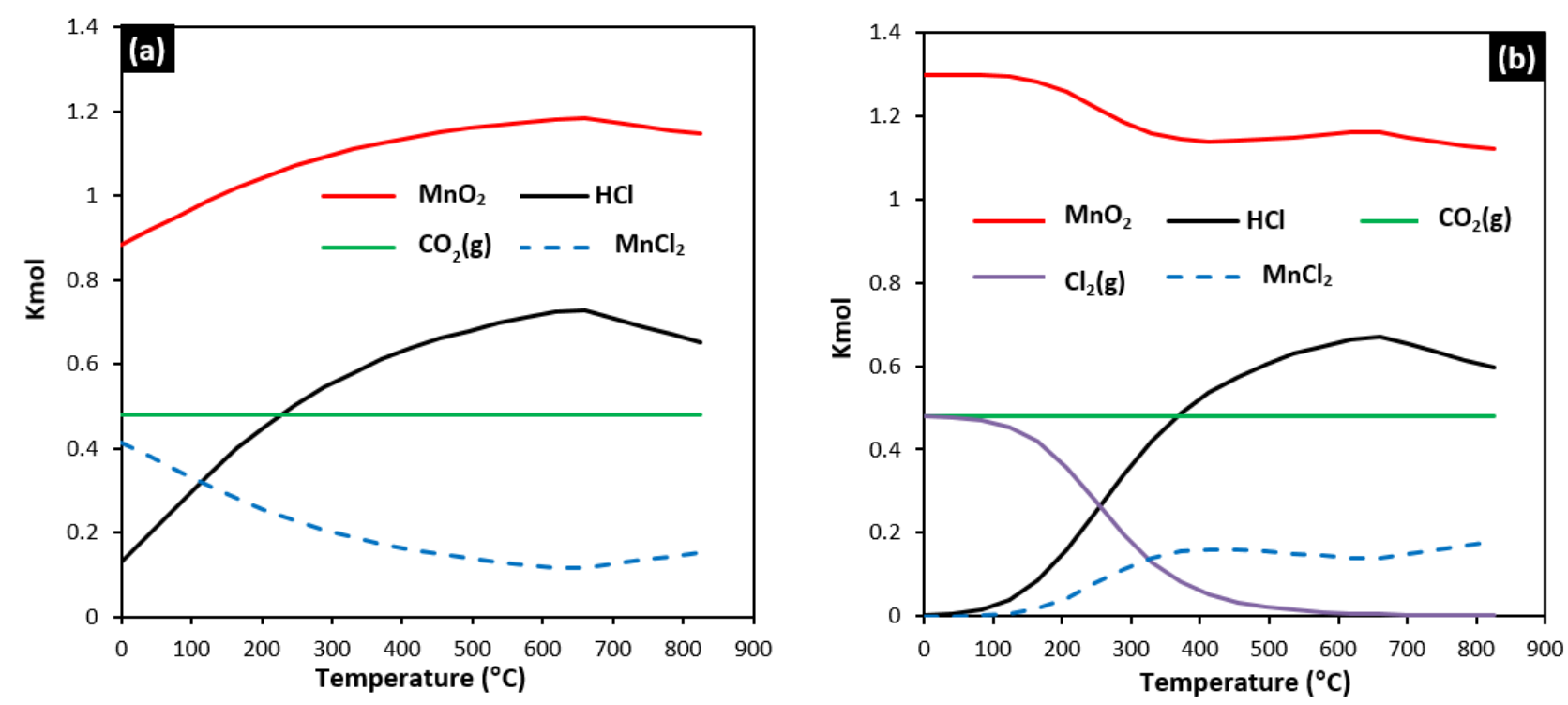

Fig. 6S. Results of thermodynamic modelling for $30 \% \mathrm{MnO}_{2}$ in the presence of water in the input (Cases 1 and 2 Table 1) a) without $\mathrm{Cl}_{2}$ in output and b) with $\mathrm{Cl}_{2}$ in output.
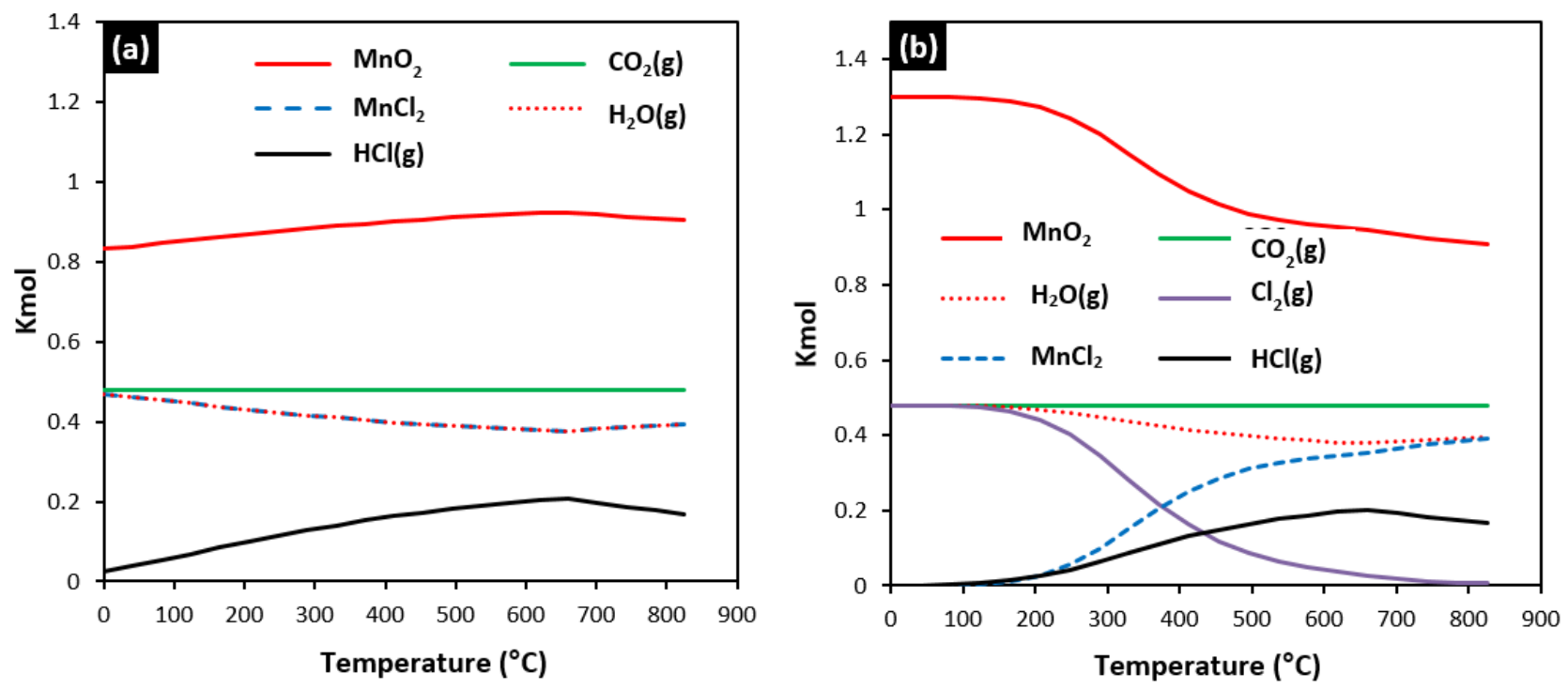

Fig. 7S. Results of thermodynamic modelling for $30 \% \mathrm{MnO}_{2}$ in the absence of water in the input (Cases 4 and 5; Table 1) a) without $\mathrm{Cl}_{2}$ in output and b) with $\mathrm{Cl}_{2}$ in output 

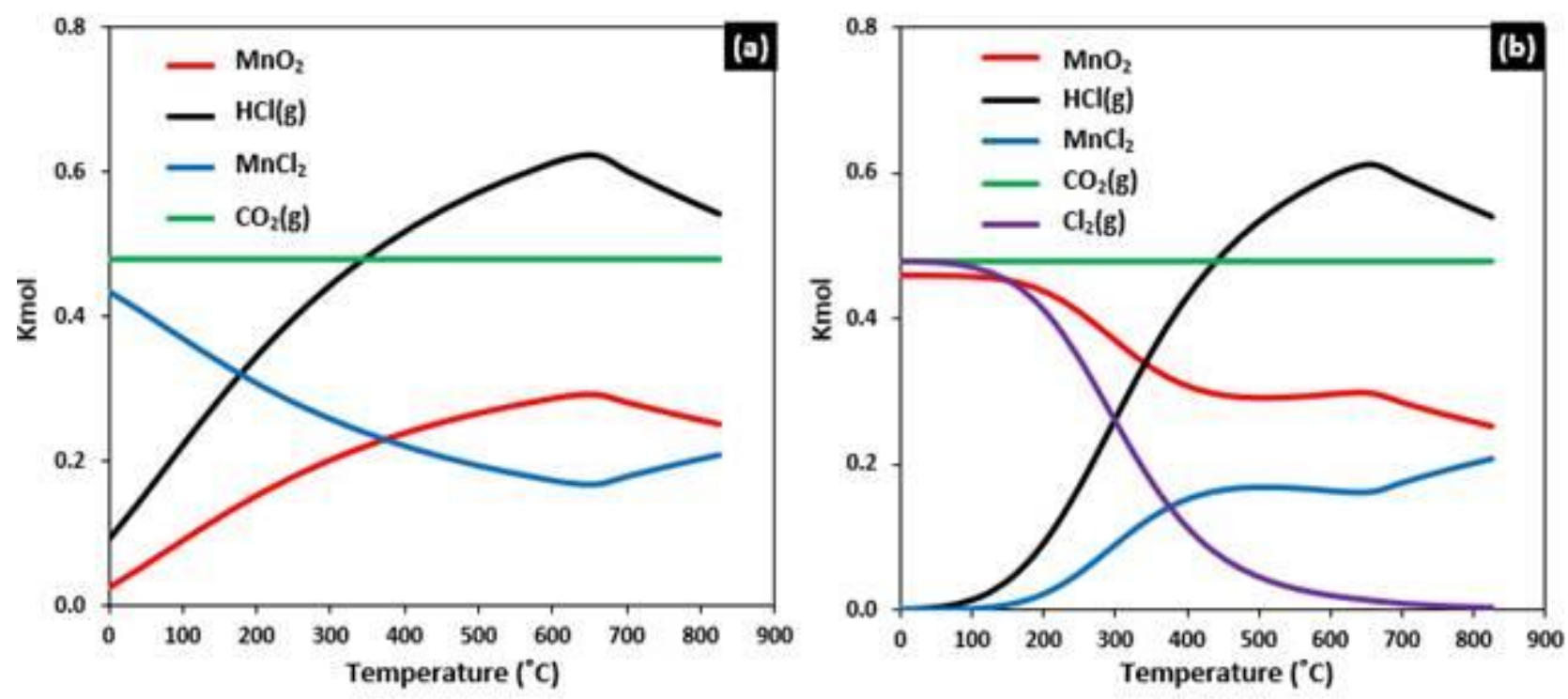

Fig. 8S. Results of thermodynamic modelling for $10 \% \mathrm{MnO}_{2}$ in the presence of water in the input (Cases 1 and 2
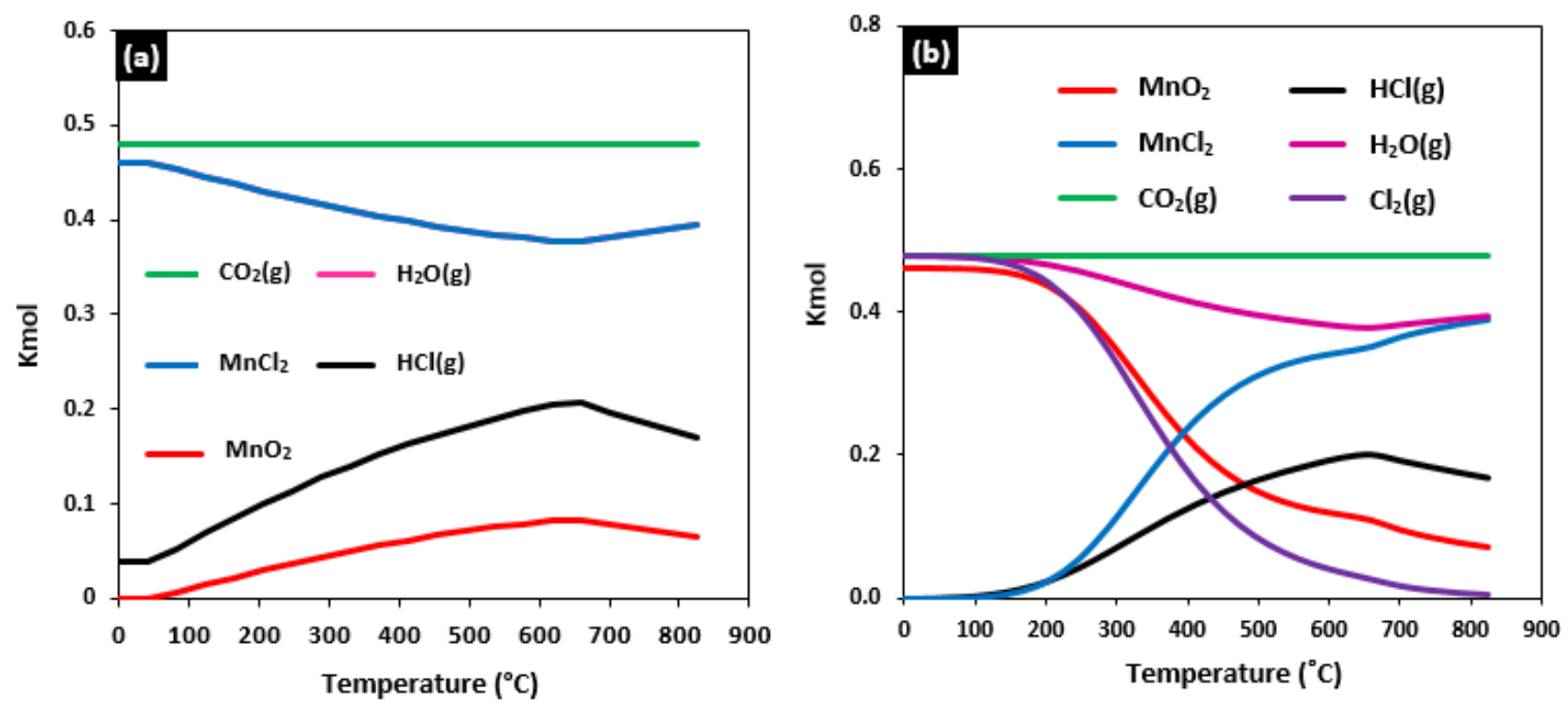

Table 1) a) without $\mathrm{Cl}_{2}$ in output and b) with $\mathrm{Cl}_{2}$ in output

Fig. 9S. Results of thermodynamic modelling for $10 \% \mathrm{MnO}_{2}$ in the absence of water in the input (Cases 1 and 2 Table 1) a) without $\mathrm{Cl}_{2}$ in output and b) with $\mathrm{Cl}_{2}$ in output 

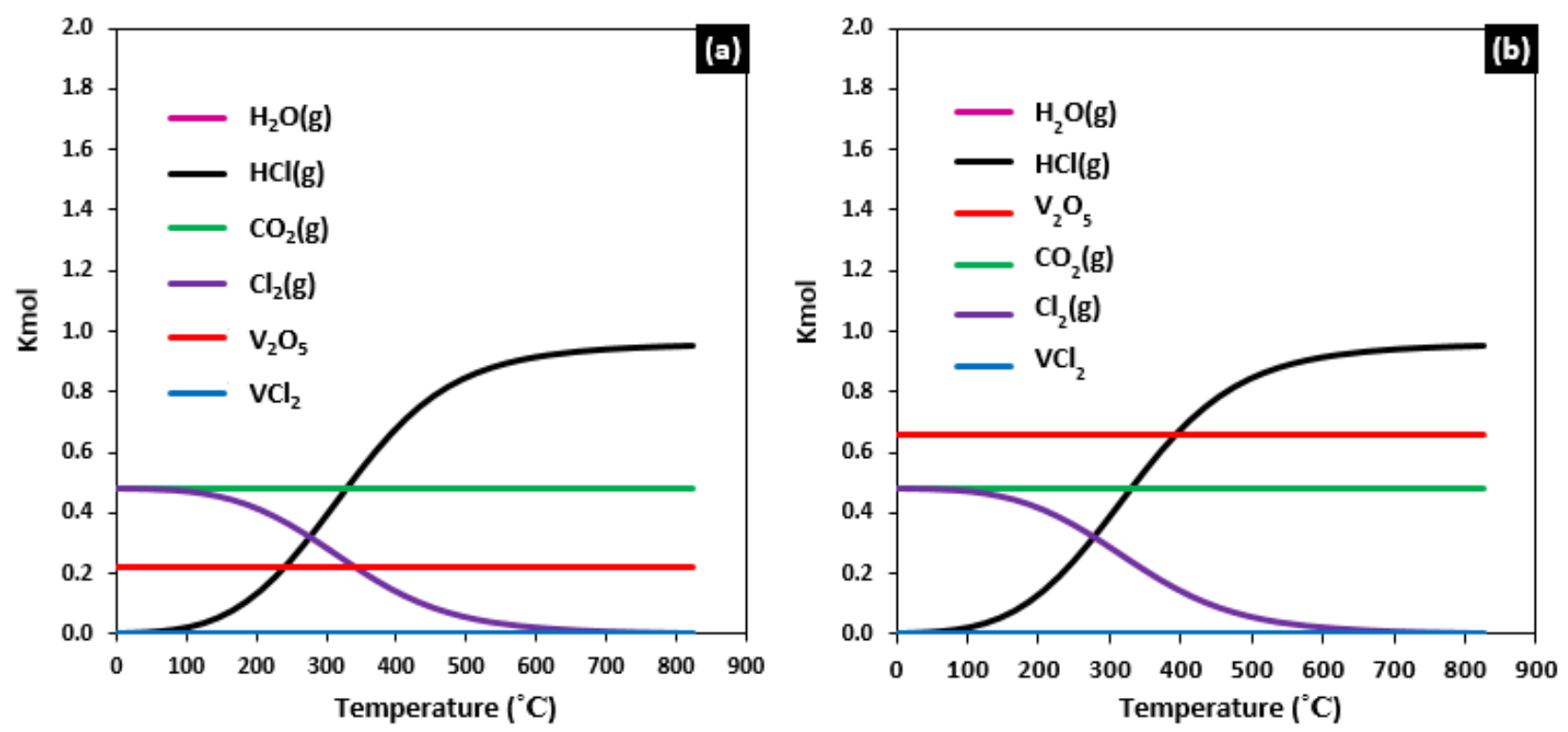

Fig. 10S. Results of thermodynamic modelling in the presence of water in the input and $\mathrm{Cl}_{2}$ in output (Cases 2 Table 1) a) $10 \% \mathrm{~V}_{2} \mathrm{O}_{5}$ and b) $30 \% \mathrm{~V}_{2} \mathrm{O}_{5}$
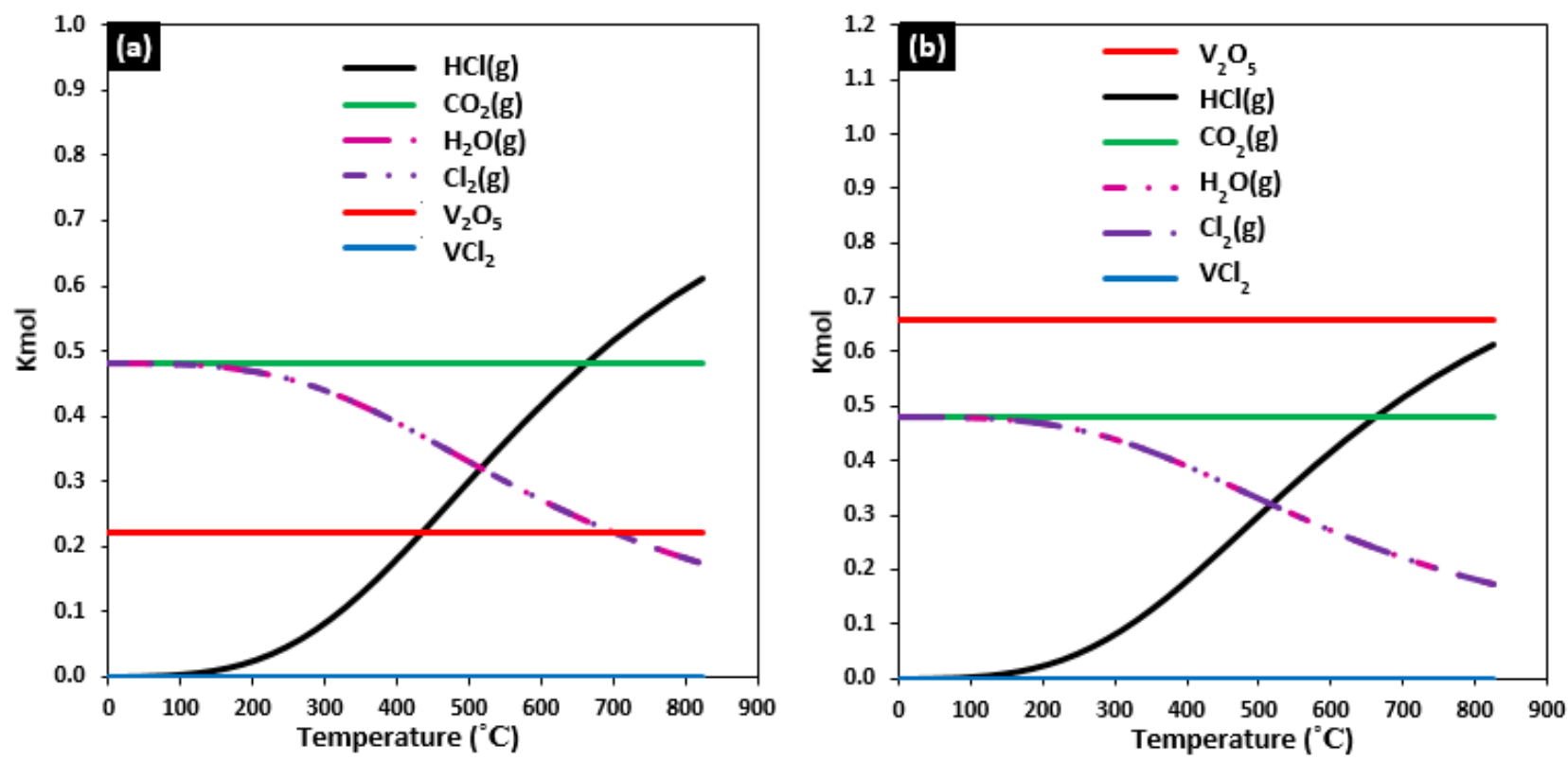

Fig. 11S. Results of thermodynamic modelling in the absence of water in the input and $\mathrm{Cl}_{2}$ in output (Cases 2 Table 1) a) $10 \% \mathrm{~V}_{2} \mathrm{O}_{5}$ and b) $30 \% \mathrm{~V}_{2} \mathrm{O}_{5}$ 